\title{
The 'Non-Unitary' Greek Codex: Typologies and Terminology
}

If we exclude-as we probably must-book production in roll format, ${ }^{1}$ the notion of a 'unitary book' is only widely applicable and entirely free of ambiguity in the world of modern publishing: a world in which a volume containing a single text by a single author, printed in a continuous and unmodifiable sequence of consecutively sewn (or glued) leaves or quires, represents the norm. The quality of being 'unitary' is, in fact, an intrinsic and essential characteristic of a 'prepackaged' product reproduced in a series of identical copies aimed, from the outset, at an audience composed of indeterminate potential buyers. Such an audience has no direct control over the selection of content or the way in which it is arranged, and is therefore quickly destined to lose any awareness-and hence any interest-in the material peculiarities of the 'container'. The absence of such a 'functional' interaction between a book's content and the sequencing of its quires-which was a fundamental characteristic of the manuscript volume's structure-firmly establishes, with only a few exceptions, the cohesion and immutability of the textual sequence, and therefore the impossibility on the part of the readers to carry out personal modifications (e.g. deletions of, and/or adjuncts to, the book's structure, or its sequential rearrangement) subsequent to their acquisition of it. ${ }^{2}$

Translated from the Italian into English by Mark Livesey. Original published as Maniaci, Marilena (2004), 'Il codice greco "non unitario". Tipologie e terminologia', in Crisci, Edoardo / Pecere, Oronzo (eds), Il codice miscellaneo. Tipologie e funzioni. Atti del convegno internazionale (Cassino, 14-17 maggio 2003), Cassino: Università degli studi di Cassino (= Segno e testo, 2), 75-107.

1 Even if not always in relation to its content, because of its particular structure, a 'book' in roll form is always, by its very nature, 'unitary', in the sense that no examples appear to exist of rolls composed of multiple parts that were originally conceived of as autonomous 'segments' which were later on spliced together to form a continuous and unbroken sequence.

2 This characteristic, which represents a radically new situation with respect to the manuscript book, cannot be attributed to purely technical issues: after all, it has been noted that late medieval readers and librarians widely employed (in printed books as well) the technique of 'bundling together' in loose successions editions of different dates and origins, and that they did not hesitate to combine in one and the same book both printed and handwritten quires 
Conversely, the manuscript codex has-by its very nature as a unique, individually handcrafted, 'custom-made' object-the potential to be 'non-unitary'. Its 'non-crystallised' content and a natural tendency towards a modular structure endows it with a high degree of 'flexibility'. It is therefore somewhat surprising that, up until now, very little attention (with a few exceptions) has been paid to these two characteristics which constitute, throughout the Middle Ages, a fundamental feature of the codex. This scant level of attention is made all the more evident by the vagueness and overall confusion that prevails in the use of specific terminology, and the obvious inadequacy of the majority of codicological descriptions provided in catalogues, including those produced in recent times and in accordance with modern rules. ${ }^{3}$

It seems appropriate to preface the following series of observations on the overall characteristics of the Byzantine 'non-unitary' manuscript with some theoretical insights vis-à-vis the basic concept of a 'non-unitary' codex. (These remarks and observations are intended as a contribution to the shared effort to systematise matters, which the Il codice miscellaneo conference bears ample testimony to. $)^{4}$

My first observation concerns the meaning-or rather, meanings-which can be attached to the term 'non-unitary'. In fact, the 'non-unitary' nature of a codex can be assessed on two different levels:

- The material level, concerning the 'structural units' which combine to form a codex and the various ways in which such units are assembled (structural

(this could be one of the reasons that made it possible for printers, in contrast to today's practice, to print editions composed of only one or two quires).

3 The following contributions (listed in chronological order) form part of the essential bibliography specifically dedicated to this theme (excluding references that are occasionally met with in works containing other material): Thorndike 1946; Robinson 1980; Hanna 1986; Kienhorst 1996 (which the present author was unable to consult); Munk Olsen 1998; Gumbert 1999, and Kwakkel 2002. Only subsequent to drafting the present contribution did I become aware of Nichols / Wenzel (eds) 1996, in which see, in particular, Shailor 1996, and Kienhorst 2002 [2003].

4 I refer, above all, to Gumbert 2004, a bountiful contribution which picks up on and examines in greater depth some food for thought presented in a previous essay (Gumbert 1999, referred to in the foregoing note), and on other occasions (Gumbert 1989). I also refer to some observations presented in the work by Muzerelle / Ornato 2004 [in this volume, 377-412]. The ideas developed in both essays, regardless of their independent origins, which makes them difficult to place within a common framework, contain significant concordant elements. A contribution to the description of the miscellaneous codex in Latin script (to be understood as 'a codex containing more than one text', without additional qualifications) can also be found in Cartelli / Palma / Ruggiero 2004. Despite being essentially palaeographical in nature, also of interest in relation to the material characteristics of codices is Bianconi 2004. 


\begin{abstract}
units may be 'codicological units', 'booklets', 'production units' and 'usage units', all of which are similar entities, but which at the same time do not fully coincide, partly due to the difficulty of defining their exact significance in a stringent way). ${ }^{5}$
\end{abstract}

5 Here, it may be helpful to the reader to make an attempt at briefly summarising the meanings of the various terms, even if they are not all defined with equal clarity within the relevant bibliographies: 'codicological unit' = 'volume, parte di volume o insieme di volumi la cui esecuzione può essere considerata come un'operazione unica, realizzata nelle stesse condizioni di tecnica, di luogo e di tempo' (Maniaci 1996 [1998²], which picks up on Muzerelle 1985; 'codicological element' = 'l'unité la plus petite qui ait pu mener une existence indépendante dans la mesure où la fin d'un texte coïncide avec la fin d'un cahier' (Munk Olsen 1998, 105). On p. 108 one can find the following clarification: 'même si l'unité codicologique et l'élément codicologique coïncident souvent, celle-là est plus vaste que celui-ci'); 'booklet' = 'a small but structurally independent production containing a single work or a number of short works' (Robinson 1980, 46). This definition is followed by a series of helpful pointers on how to identify a 'booklet', which can be composed of one or more quires and can be of different dimensions and structural forms, and can also bear scripts and decorative elements different from the rest of the codex it forms a part of. A 'booklet' is often endowed with independent quire signatures or catchwords and concludes with a quire of anomalous composition. A 'booklet' can also show signs of previous independent circulation, such as soiled or faded/discoloured outer leaves; 'production unit' = 'group(s) of quires that formed a material unity at the time of production [...] copied 'in one go', by either one or more scribes' (Kwakkel 2002, 13-14; the author underscores an affinity with the definition of a 'booklet', albeit making it clear that while the latter is of limited thickness, a 'production unit' has no limit to its bulk and can even represent an entire codex); and finally, 'usage units' = 'an abstract notion that refers to the manner in which a production unit was used: separately or bound together with other production units' (Kwakkel 2002, 14, further specifying that 'a group of quires $<$ that $>$ form a production unit are also part of a particular usage unit'). All the definitions provided are intended to address the need to distinguish, within a codex or portion of a codex that was planned to be unitary (i.e. a 'codicological unit' in its traditionally accepted sense), quires or coherent sequences of quires that are structurally independent. In contrast to the 'codicological element' (which I do not believe is automatically comparable-as Gumbert 2004, 25 seems to contend-to the 'codicological unit' and the 'production unit'), the 'booklet' is characterised by greater textual autonomy and a more marked propensity towards independent circulation. Establishing the degree of collaterality between the notions of (a) 'codicological unit' and (b) 'usage unit' is, to my mind, more difficult, since these tend to be equivalent to each other in cases where multiple 'production units' were originally conceived of to be combined (sooner or later) to form a single volume, but not in cases where 'usage units' composed of multiple 'production units' were created using different techniques in different places at different times. As will become apparent, the specific nuances of meaning carried by each of the terms make it impossible to establish clear parallels between them. As regards the 'meeting points' between concepts and terms suggested later on in this contribution and the copious, well-formulated terminology proposed by J.P. Gumbert, I shall confine myself to referring back to the material found in the notes accompanying his contribution. 
- The content level, where the notion of 'non-unitary' is characterised by multiple gradations-frequently perceived of and described in incorrect, or at least inadequate, ways-both among 'mono-textual' and multi-textual' codices.

With regard to the script-which should naturally suggest a third approach to examining the 'non-unitary' codex, quite distinct from the two listed above-clearly, the simultaneous presence of different scribes' hands has to be regarded as a factor that is far from irrelevant to the creation of a codex, but at the same time one which does not represent, within the framework of the subject presently under examination, an operative criterion, inasmuch as it is compatible with the entire spectrum of possible situations (ranging from the alternation of different scribes working on a 'unitary' codex, to the merging of units originating from different or independent projects). The interaction of the script with a volume's material structure and its content must therefore be assessed on a case-by-case basis, and does not constitute, within the framework of a codicological investigation, a fundamentally and systematically relevant variable. ${ }^{6}$

The two levels-materiality and content-interact in complex ways which cannot easily be reconciled with universally valid interpretative frameworks, as demonstrated by the highly variegated nature of the available documentary evidence. However, these interactions can be evaluated not only on a case-by case-basis, but also in terms of overall trends, frequency of occurrence and degrees of cohesion, and therefore the underlying extent of planning.

From the material point of view, the 'non-unitary' codex always represents the final product of an operation that we can define as an assemblage, which is to say the result of the merging into one entity of a unique sequence of multiple groups-or blocks-of quires. Irrespective of the fact that these blocks were conceived of from the outset with the intention of uniting them into a single aggregation, ${ }^{7}$ the necessary prerequisite in order to adjudge a volume as being materially 'non-unitary' is that the quires or groups of quires that compose such

6 This is not in any way intended to diminish the value of a specific study of what have been defined as 'miscellaneous hands' (Bianconi 2004, 315), whose motivation and working dynamics are very effectively summarised in Cavallo 2001. Needless to say, whenever a change of writing hand is associated with the appearance of a new text and/or quire, this can represent a valuable 'clue' for the analysis, but at the same time can also simply be the result of the collaboration of multiple scribes alternating during a volume's production, and therefore does not constitute, ipso facto, a determining factor in the present discussion.

7 This is something that cannot always be established with absolute certainty, as it will be shown later in this article. 
blocks be arranged in a series of textually autonomous, modular units. A modular unit-which in essence corresponds to the élément codicologique of Birger Munk Olsen ${ }^{8}$-is a quire or group of quires that opens with the beginning of a text or a clearly defined textual partition, even if it is not necessarily an autonomous one (such as an individual biblical book), and concludes, likewise, with the end of a text (although not necessarily the same one), or with one of its internal partitions. ${ }^{9}$ The caesura between individual modular units, which is often visually highlighted by the presence of one or more quires of different thickness (i.e. number of leaves) in comparison to the others, can persuasively be identified by the term junction (Italian: snodo). ${ }^{10}$

Meanwhile, an assemblage can be observed as the visible product of several distinct processes (which may have accumulated during the production of a single volume). These processes include:

- Accretion, in cases where single quires or groups of autonomous quires have been transcribed separately by one or more scribes-possibly on the impulse of an 'inspirer' or 'coordinator'-in multiple, more or less contem-

8 See footnote 5 , above.

9 In truth, the question as to whether or not the 'textual completeness' criterion (which is to say the possibility of identifying this element by using a concise term that neatly summarises a work's content) is sufficient for the purpose of defining a modular unit ought to be examined in greater depth. The answer to this question depends on the exact definition of the term modular unit, which may or may not subsume the concept of interchangeability. For example, three quires in succession which start with the $4^{\text {th }}$ canto of the Iliad and conclude with the end of the $6^{\text {th }}$ canto of the same work present as a synthetically definable modular unit, but form part of a textual sequence that cannot be altered. In other cases, the modular unit is textually and codicologically autonomous, but was not planned to be this way if the quires bear a (quire) signature (a strictly coeval one, needless to say), or if the preceding and successive quires bear a catchword. It is therefore necessary to distinguish between codicological autonomy and textual autonomy, and in the latter case between 'virtual' autonomy (in theory the sequence of elements is 'open', but in actual fact is as good as pre-established during the planning stage), and 'real' autonomy (where users of the volume are afforded the possibility of shuffling the order of the texts). On the other hand, autonomy can be understood as exclusively 'internal' (i.e. interchangeability is limited to being intra codicem), or sometimes 'external' (i.e. when interchangeability means inter codices). Defining these criteria is not an entirely superfluous task, but instead represents a valuable tool to assist in reconstructing the 'genetic dynamics' of a book.

10 Snodo is a term that I have previously introduced and defined in Maniaci 2000, 54 [in this volume, 35-63]. It is the same phenomenon for which Peter Gumbert coined the term 'caesura' (Gumbert 2004, 24, although the same term had already been employed in Gumbert 1989). The phenomenon is referred to by Frank Bischoff as a 'Lagenbruch' (Bischoff 1994). It seems to me that the term 'junction' more aptly describes the interruption in continuity between two blocks, not only in terms of a 'breakage' but also in the sense of an 'intersection'. 
poraneous stages, or alternatively when quires were transcribed over time, with the original intention of combining them and ultimately binding them together to form a single volume.

- Convergence, when single pre-existing quires or groups of quires, both contemporary or produced at different times, pre-existing quires, and having different origins (perhaps even previously inserted within other structure) are merged to form a new volume on the initiative of a user or librarian. In these instances, we can further distinguish between:

- Functional convergence, if the merging of the quires was made on the basis of a clearly identifiable, or alternatively, presumptive logical criterion, already during the Middle Ages.

- Practical convergence, if the merging took place without the application of any specific criteria and was carried out simply to preserve the relevant material in the post-medieval period.

Here, it should be pointed out that assemblages of modular units are not all attributable to accretion and convergence phenomena. In other words, modularity does not necessarily only correspond to a specific aim, but can also represent the spontaneous result of a specific transcription method, which is to say a distributed copying process aimed at achieving an efficient division of labour amongst multiple scribes working contemporaneously. In this instance, one can speak of concomitance.

Looking beyond specific contexts such as the Latin pecia system, ${ }^{11}$ it is difficult to attribute the result of a concomitant transcription project purely to the desire to organise labour in an efficient way. One has only to recall the case of many of the Latin 'Atlantic' Bibles which, even if they are characterised by an obvious unitariness in their planning (inasmuch as the individual modular units were destined from the outset to be merged into a single volume), present a material configuration that consists of blocks of quires that correspond to definite textual sequences whose precise purpose can probably be ascribed to the

11 Here, it is perhaps not entirely pointless to emphasise that the pecia system was based on the preparation of structurally unitary exemplaria (given that individual binions do not coincide with the subdivision of the text and are not necessarily configured as modular units), which in turn result in perfectly unitary apographs (in theory, at least). Therefore, we are dealing with a purely material modularity 'of convenience', and hence one which is completely different from the modularity that characterises the 'non-unitary' manuscript. 
simultaneous presence of multiple motivations, the interrelationships of which have yet to be determined with greater clarity. ${ }^{12}$

Finally, additional assemblage processes can be placed within the sphere of preservation and 'restoration' activities: for example, a tattered or lacunaeriddled codex might have been completed by adding substitute, purpose-made quires or, more rarely, pre-existing ones. These instances-which can be referred to by the technical term reintegration-do not consist in 'constructing' a new volume or even in completing an already existing one, but rather in reinstating an existing volume's (or series of volumes') integrity.

Convergence is usually quite easy to recognise, inasmuch as it often results in considerable negative consequences for the aesthetic quality of a volume; indeed, only rarely (above all in parchment codices) do the dimensions of sheets match up sufficiently well so as to avoid the need for unsightly trimming. Similarly, it only seldom happens that dimensions match well and that the layout and script are free from obvious irregularities.

By contrast, accretion and, above all, concomitance can intentionally be hidden, even if surviving codices clearly demonstrate that concern for this issue was not as great for medieval artisans as it is for us in modern times. Thus, in parchment codices, where there was a tendency to avoid waste, modularity often involved variations in the 'normal' quire structure, not infrequently accompanied by, in the case of concomitance, simultaneous changes of scribes' hands, and therefore irregularities in the transcriptional flow (e.g. variations in the rate of abbreviations, drafting or 'compression' of the script, and oscillations in the number of lines, or other components of the mise en page). In the paper codex, because of the lower cost of the raw material, the 'normal' quire structure tends to be maintained, with the result that empty leaves are often found at the end of the final quire in a modular unit. Such empty leaves were often quite rapidly occupied by microtexts of various kinds that were inserted in the blank spaces in order to fill them.

If confined to the 'archaeology' of the codex, the strict dichotomy suggested by the terms 'unitariness' and 'non-unitariness' can in any event be split into an

12 In any event, it would be excessively reductive to attribute the Atlantic Bibles' 'articulated' structure purely to the necessity to create rational subdivisions so as to distribute transcription tasks among multiple scribes working simultaneously. The legacy of a tradition accustomed to viewing the Bible as the sum of independent parts rather than as a unified whole; the availability of different models to base individual sections on; and the desire to facilitate (even if only to a limited extent) the 'decomposition' and 'recomposition' of the textual sequence in relation to specific requirements, could all have played their respective roles: roles which are now difficult to determine with any degree of certainly. See Maniaci 2000, 57 [in this volume, 35-63]. 
array of tangible possibilities. However, drawing a correct and precise distinction between these represents an essential prerequisite, regardless of whether one's aim is to carry out a descriptive task or alternatively to reconstruct the 'genesis' of individual items, with related operative and functional implications, or implications of a cultural nature in the broader sense. (I do not believe that the two contrasting points of view should be seen in opposition, but rather as being complementary to each other.) The situation is further complicated whenever the antinomy 'unitary' codex / 'non-unitary' codex is applied not to a volume's structure, but instead to its content.

It is only natural to consider the 'mono-textual' codex as an example of 'unitariness' par excellence. The classic model of a 'mono-textual' codex is, of course, one which contains a single work by a single author, but the definition can be extended to manuscripts that contain one or more internal partitions within one and the same work-in other words, one or more textual units that have the quality of seeming textually complete and whose separate circulation is deemed acceptable (e.g. a complete edition of the Odyssey, a sequence of its constituent books, or even a single book). The most representative example of this phenomenon is, of course, the coupling of the sequence of writings composing the Old and New Testaments. Indeed, based on the criterion set out above, a codex containing the entire Bible would clearly have to be termed 'mono-textual', just like one that contains a single book of the Bible (a classic case being the Psalms), or a specific sequence of books, such as the Octateuch or Prophets.

Quite distinct from codices that are purely 'mono-textual' (but which at any rate are similar to these), are volumes that, despite containing multiple independent texts, share a 'unitariness' in terms of authorship which is normally associated with a 'unitariness' of genre (e.g. the Tragedies of Aeschylus, Plato's Dialogues, etc., but also a combination of theological treatises and homilies of Basil the Great or Gregory of Nazianzus).

Conversely, the association of multiple works or multiple textual units by different authors gives rise to a multi-textual codex, which can be identified by the following key requisites:

1. The individual units that make up the codex do not form part of the same work, nor is it composed of different works by the same author.

2. The sequence in which the units are arranged is not indispensable to understanding the text, and can therefore be altered without resulting in any serious consequences with regard to the text's proper use. 
In cases where textual units are particularly slim, which is to say ones that are materially underdeveloped, recourse to the multi-textual codex can be seen as a necessity in order to permit the transmission of units which on their own could not constitute an autonomous codex. The 'automatic' reaction to the apparent contradiction between codex thickness and text length consists in putting together in one and the same volume two or more textual units in order to reach a minimum thickness threshold (or overall thickness), which then makes it acceptable to produce an independent volume. The threshold-both on an individual basis and systematically-varies over time and in relation to the dimensions of volumes (this point will be further addressed later on when examples will be given). ${ }^{13}$ This approach has often been the 'default' method employed by librarians in modern times, who in this way have indiscriminately assembled entire codices, incomplete texts, and even mere fragments, thereby creating jumbled composite or incoherent multi-textual sequences.

However, in the historical period when the codex had an intrinsic value to its users, and hence its content was conditioned by readers' needs, the aforementioned purely 'automatic' approach represents an exception. Instead, the tendency was to favour the production of organised multi-textual sequences or semi-organised multi-textual sequences-in other words, textual juxtapositions inspired by some logical principle or another (which remains more or less evident and comprehensible even many centuries later).

When one and the same sequence of textual units 'crystallises' and is reproduced in identical form over a period of time, we can speak of a corpus, or sylloge (although the use of the latter term should be limited in order to avoid confusion). ${ }^{14}$ Here, the term sylloge can be defined as an arrangement of intellectually and 'genetically' independent textual units which are more or less firmly canonised in the manuscript tradition, and sometimes identified by a title explicitly inscribed in the actual volumes, or simply codified by oral use (e.g. anthologies of epigrams, series of 'thematic' orations, compilations of legal rights, etc.).

Within the framework of the set of problems presently being addressed, it is very important to differentiate between sylloges and multi-textual sequences, be they fragmentary or organised or semi-organised (i.e. collections/compilations of

13 See below.

14 In fact, it is important to clearly distinguish, both conceptually and terminologically, between the 'bundling together' of complete texts by one or more authors in one and same volume, and the compilation of excerpta, which is also known as a sylloge (see, for example, Odorico 1990), which I would prefer to define as a 'compendium'. 
rhetorical, grammatical or medical texts, etc., or lives of the saints, epistolary works, collections of apophthegms, etc.) in the form of improvised and variable juxtapositions of textual units which, being more or less loosely related, but in any event not sufficiently so to engender-intentionally, at least-a new and enduring tradition (such as a textual typology, or the tastes/needs of a particular milieu or circle of cultured readers, or even the personal interests of a specific learned figure).

The sylloge is rather more difficult to qualify with respect to the concepts of work or 'mono-textual' codex. In the first place, here it should be reiterated that the internal segments of a work of unitary conception, such as the aforementioned books of Homer (even if they can be transcribed separately and could potentially become part of a sylloge) do not constitute, when taken as a whole, the elements of the sylloge, inasmuch as they have never enjoyed a fully independent existence. The same applies:

- To textual units that can be defined as open, such as chronicles-which are often subject to one or more continuations (which almost always, in the manuscript tradition, end up being incorporated in the antecedent text without interruption).

- To so-called satellite texts (i.e. indexes, prefaces, brief introductory biographies, etc.) which, despite not being 'genetically' coeval with the 'planet' they relate to, enjoy only an-as it were-'reflected' existence and circulation.

The juxtaposition of open textual units and their continuations, or that of 'planets' and their 'satellites', does not in actual fact generate truly multi-textual sequences.

A particular case concerns textual commentaries, which it seems logical to regard as being an integral part of a 'mono-textual' codex when they coexist on the same page as the text to which they refer in the form of a gloss, irrespective of its layout (i.e. as an interlinear gloss or one framing the principal text). The situation is different with respect to commentaries attributable to specific authors, which may have a materially autonomous tradition, or could possibly be associated with the text in the form of a separate textual unit, hence in multitextual contexts.

The above being said, a sylloge (which is marked by varying degrees of internal organisation) can be characterised, on a strictly typological level, according to its 'genetic' features. This gives rise to the following instances:

- An original sylloge: when a series of 'excessively' slim textual units (i.e. epistles, homilies, epigrams, fables, eclogues, etc.), which were not envis- 
aged to be grouped together in an intentionally unitary scheme, are collected, placed in order and disseminated by the author himself or by his circle, and thereafter perpetuated in an almost unchanged form.

- A sylloge of erudition: when a series of textual units that have already been circulated separately within the tradition (but not independently as autonomous units) is intentionally collected, arranged in order and disseminated by a learned figure (or circle) on the basis of one or more common denominators that ensure the cohesion (of author, themes, literary genre, study or reading interest) and various other criteria that justify the chosen order (chronological sequence, pericope, etc.). Such syllogai were also meant to fulfil specific ends (liturgical services, religious devotion, teaching etc.).

- A sylloge of transmission: when a series of textual units that are already circulating independently of each other are for the first time juxtaposed in a codex for reasons of mere convenience (in other words, without the application of any predetermined cultural criteria), and are subsequently transmitted in exactly the same way purely on account of inertia (i.e. the lack of sufficient material or intellectual impetus to give rise to the creation of a more satisfactory alternative).

To the first two categories of sylloge (original and of erudition), we can attach the interdependent notions of pertinence and stability. The repletion of a sylloge depends on the strength and cogency of the (internal and external) criteria that determine its fundamental cohesion and justify the chosen order of its content. The notion of stability has to do with the quantity and sequencing of the textual units merged into a sylloge: this will be at its maximum when the various writings in a given sylloge occupy the same number of textual units arranged in the same order.

With regard to the relationship between the concept of a sylloge and that of work (and of 'mono-textual' codex), original sullogai can unquestionably be likened to individual works, since their component textual units have never enjoyed independent dissemination, or at least independent 'publication'.

The situation becomes more complicated as far as syllogai of erudition and syllogai of transmission are concerned. In particular, the identification of a sylloge of erudition cannot be based on a purely codicological criterion: perception of its textual units as an inseparable whole that cannot be modified does not necessarily presuppose the materially unitary nature of a codex, quite apart from the fact that even a simple improvised multi-textual sequence can sometimes be the result of the direct copying, into a materially unique object, of individual textual units drawn from different codices. In the absence of information 
that cannot be reduced to a simple enumeration of texts and their sequence within a codex, the only realistic possibility is to apply a statistical criterion, namely positive ascertainment that the tradition records a certain number of copies containing exactly the same arrangement of texts. However, boundaries in the world of statistics are always somewhat blurred-indeed, what is actually meant by 'a certain number'? In the strict sense, one can only speak of a sylloge when at least two multi-textual (and normally, though not necessarily, 'unitary') codices exist that present sufficiently similar textual sequences-in terms of type, number and order of the texts-so as to be able to exclude the possibility of chance convergences. This definition of a sylloge is technically satisfactory on condition it is accompanied by accurate and detailed historical and philological analyses. ${ }^{15}$

Finally, the dynamic implication inherent to the concept of sylloge should be stressed here. An extemporaneous collection can, in fact, be transformed into a sylloge if the personality behind its creation is sufficiently authoritative on the intellectual plane and has at his/her disposal a library, or is in charge of an institution capable of functioning as a dissemination hub. A sylloge of transmission can be transformed into a sylloge of erudition if it is purposefully introduced into a study and teaching circle, perhaps then becoming the object of glosses and added commentaries. In turn, syllogai of erudition can be compared to living organisms-indeed, they can continue to develop when further textual units are added, subsequent to new discoveries or the acquisition of new texts, or if new demands emerge. Conversely, they can 'die' if the texts they are composed of cease to be relevant to the 'active' interests of a particular community or intellectual circle. Additionally, they can become 'fossilised' as a result of the tradition's intrinsic mechanisms.

The tentative effort made to keep the two levels (i.e. material and textual) separate from one another during the analysis of the pairing 'unitary' codex / 'non-unitary' codex is the reason why all references to the current Italian terminology have deliberately been avoided up to this point. Indeed, it seems to me that the Italian terminology is even more inadequate and misleading than I judged it to be a few years ago, when I was working on the Italian version of Denis Muzerelle's Vocabulaire codicologique. ${ }^{16}$

15 In any event, it is clear that for the purposes of defining a sylloge the co-presence of four textual units in two almost contemporary copies originating from the same production centre is not as compelling as the co-presence of fifteen textual units in numerous copies transcribed over an extended period of time in places or contexts distant from each other.

16 Muzerelle 1985; Maniaci $1996\left(1998^{2}\right)$. 
The problematic ambiguity arises from the fact that the lexicon currently employed implicitly codifies a double juxtaposition between the terms 'unitary' and 'miscellaneous' (in reference to content) and 'unitary' and 'composite' (in reference to the physical structure of codices, and specifically to their subdivision into independent, juxtaposed units). Instead of helping to fully define, from two complementary viewpoints, one and the same thing, the two attributes 'miscellaneous' and 'composite' are mistakenly perceived of as opposites (i.e. a codex is either 'miscellaneous' or 'composite'). Further confusion arises due to the lack of a clear correspondence between the Italian terminology and terminologies established in various other languages, including Latin, in which the term miscellaneous is applied (in the catalogues of Greek codices held in the Vatican Library's collections, for example) to volumes traditionally described in Italian as 'factitious composites' (compositi fattizi, jumbled composites). ${ }^{17}$

Only a simultaneous examination of the two levels-material and textual-will lead to the development of a nomenclature that satisfactorily takes their interrelationship into account. A complete and fully fit for purpose terminology-which would be premature to propose in the present context ${ }^{18}$-should take into account, as far as the mono-textual codex is concerned, the following possibilities:

- A mono-textual, mono-block codex, unitary both from a material and structural point of view. This represents the least complicated situation, and equates to the transcription of mono-textual content (a complete work, portion of a work, group of works by the same author, or sylloge) in a single codicological unit, conceived of from the outset in such a way so as to make subsequent dismantling and reassembly in sequences different from the original impossible, or at any rate not without causing irreversible damage to the original structure of the volume (i.e. dismemberment of quires that were originally all of the same composition and complete).

- A mono-textual, multi-block codex, that is a structurally 'non-unitary', mono-textual codex, which is to say one that is composed of 'adjustable' units which have the potential to be reassembled into forms different from the original (in response to the later emergence of new, collective or indi-

17 Maniaci $1996\left(1998^{2}\right), 76$.

18 The terms employed here-which are aimed at achieving conceptual clarity rather than linguistic elegance-have the sole objective of presenting the fruits of a first attempt at the conceptual organisation of a set of problems that requires further, in-depth reflection before it will be possible to 'crystallise' matters on a terminological level (see, in relation to the danger of an excessively hasty definition of phenomena based on a still unclear scientific picture, the remarks made in the Introduzione to Maniaci 1996 [1998²], 16). 
vidual, cultural needs). From a 'genetic' perspective, this typology can in turn correspond to two distinct situations:

- A mono-textual, multi-block synchronic codex, consisting of a juxtaposition of independent codicological elements (i.e. blocks), which were distinct from each other from the moment of their creation, both on account of a respect for a pre-existing tradition and as a result of the application of specific practices regarding the division of labour and/or in anticipation of other uses (such as in the case of pre-12 $2^{\text {th }}$-century Latin Evangelaries, in which each of the four Gospels are perceived of as separate units, ${ }^{19}$ and, likewise, in the case of the aforementioned Atlantic Bibles). ${ }^{20}$

- A mono-textual, multi-block diachronic codex, which presents in the form of a sylloge whose circulation is attested to within the tradition (also in partial forms). Such volumes could be expanded through the successive addition of fresh elements (e.g. in the case of corpora of philosophical, theological, homilary and literary writings etc., by one and the same author).

In the case of a multi-textual codex, the following instances have to be considered:

- A multi-textual, mono-block codex: unitary, from a structural standpoint, in which a succession of texts is housed within a single, coalescent container, without any intentional correspondence between the ends of individual texts (or portions of the same) and the ends of quires, thereby making it impossible to alter the original sequence, if not at the cost of causing irreversible changes to the volume's original structure. ${ }^{21}$

- A multi-textual, multi-block codex: non-unitary, from a structural standpoint, composed of a juxtaposition of modular units that are materially independent and textually autonomous (codicological units; 'elements', each of which corresponds to one or more coherent units of text; booklets which have enjoyed independent circulation from the time of their original production).

In turn, the multi-textual, multi-block category includes a host of other possible situations which, in order to be accurately defined, have to be broken down by drawing further distinctions.

19 See Bischoff 1994, passim.

20 Possible (and I would say highly likely) evidence of similar practices in the Byzantine sphere has yet to be investigated.

21 This typology is commonly identified by the current Italian terminology as a miscellaneous volume, or miscellany: Maniaci 1996 (1998²), 211. 
The first distinction concerns the presence (or absence) of an underlying plan which unfortunately is not always recognisable after-the-fact) behind what we have defined as the assemblage (by means of accretion or convergence) of individual parts. Accordingly, we have:

- Organised multi-textual, multi-block codices (whose governing logic and degrees of internal organisation have to be evaluated in separate steps), which the current glossary/lexicon, in an apparent contradiction of terms, would have us define as 'unitary composites', although in fact it would be preferable to define them as planned composites.

- Random multi-textual, multi-block codices, generated by purely external needs and conservation objectives. Otherwise referred to as random composites.

Upon closer inspection, a similar distinction-based on the 'underlying plan' criterion-could be extended to the multi-textual, multi-block codex, even if such volumes generally tend to exhibit a certain degree of organisation of their content, on condition they are not merely the 'automatic' result of the copying of a random multi-block antigraph.

On the other hand, it should be emphasised that-contrary to what one might expect-the difference between multi-textual, mono-block codices and organised multi-textual, multi-block codices has no discriminating value, if the goal is to analyse the general tendencies lying behind the association of the texts, as determined by their quality, quantity, or position in the sequence, and defined by the scribes or by their commissioning clients. Needless to say, the histories of individual organised multi-textual, multi-block codices are another matter altogether: for these, only individual detailed analyses-inseparable from a specific knowledge of the historical figures and cultural contexts that each witness is rooted in-opens the way to understanding the original driving force behind their planning and development, and the working methods employed in their design and preparation. ${ }^{22}$

Another distinction stems from the fact that the formation of a multi-textual, multi-block codex is not necessarily always the product of work carried out at a fixed point in time. In fact, it can sometimes be the case that a particular juxtaposition of texts and structural units reaches its definitive form by means of a process of 'stratification' occurring over an extended period of time (ranging from a few months to many years), but this does not mean that such a juxtaposition is ascribable purely to chance. In the case of this phenomenon, then, one

22 See, for example Bianconi 2004. 
can speak of a stratified (or cumulative) multi-textual, multi-block codex (random or organised). Such a cumbersome definition corresponds to a highly varied and rather fuzzy 'category of convenience', and is therefore emblematic of the complex phenomenology of the 'non-unitary' codex.

Here, it is not superfluous to point out to the reader that the distinctions made, despite being useful as a general frame of reference, fall far short of exhausting the entire range of possibilities which have been documented, especially when one considers the fact that an originally mono- or multi-textual codex can be the product of an accumulation of multiple, concomitant circumstances.

Finally, in order to complete our review of the 'desired' terminology, it only remains to touch on an issue that will be revisited in the second part of this contribution, namely the characterisation of the 'non-unitary' codex from the standpoint of the texts it contains, both in terms of their organic arrangement (i.e. homogeneity/heterogeneity), and of what we could call the index of multitextuality (i.e. the number and lengths). ${ }^{23}$

The complexity of the picture which has emerged above could easily lead one to conclude that any hypothetical approach to the 'non-unitary' codex based on descriptions provided in catalogues would in all likelihood be a futile endeavour, given that such descriptions do not remotely furnish, in a clear, exhaustive and, above all, systematic way the requisite information on the relationship between the 'physical book' and the 'intellectual book'. ${ }^{24}$

Despite the fact that, in general, the information found in them is fairly scant and rather heterogeneous in terms of quantity and quality, catalogues nevertheless remain-given the impossibility of directly examining, in detail, the structure and content of meaningfully large samples of codices-the only available resource that makes it possible to attempt a first broad approach to attaining a better understanding the physiognomy of the Byzantine 'nonunitary' codex. Necessarily richer in useful data as regards the associations of texts found in codices, catalogues also provide the basis, albeit not an optimal one, to assemble some observations on the material structure of the 'nonunitary' codex.

The following observations are based on a systematic perusal of a large part of the modern catalogues of Byzantine manuscripts held in the Vatican Library (totalling approximately 1,500 shelfmarks), which made it possible to compile a

23 The issue is amply addressed, in respect to the Latin codex, in Muzerelle / Ornato 2004, 61 ff. [in this volume, 377-412].

24 Gumbert 1999, 27. 
database of some 1,435 items (excepting post $16^{\text {th }}$-century codices and a certain number of difficult-to-define cases). ${ }^{25}$

Besides essential chronological data (i.e. the dating of the entire codex or of its constituent parts, either to a specific century, or sometimes straddling two successive centuries) and basic codicological data (i.e. support type, number of leaves, prevailing quire structure, total dimensions, layout and number of lines), for each 'non-unitary' codex the following details were recorded: the number of texts contained in the volume; the length (in number of leaves) and the position of each of these in the sequence (limited to the first five texts); and the total number of 'brief' texts, i.e. (according to established conventions) texts composed of fewer than five leaves. ${ }^{26}$

The trickiest operation-and one which unfortunately is subject to a wide margin of uncertainty-consisted in the classification of codices into three groups, namely unitary codices; multi-textual, mono-block codices (so-called miscellaneous codices); and multi-textual, multi-block codices (so-called composite codices). Given the impossibility of carrying out a direct verification of all the individual codices, it cannot be excluded-indeed, it is altogether likely-that both the monotextual and multi-textual, mono-block categories contain, from a strictly material point of view, an indeterminate number of 'non-unitary' volumes. Even more complex, and only partially inferable from catalogue descriptions, was the identification, within the multi-textual, multi-block codex category (without question the most varied) of the various documented phenomena, ranging from the aggregation of multiple blocks transcribed by one or more copyists that were intended from the outset to form part of a single volume, to the merging of coeval (or almost coeval) originally autonomous codicological units (produced by one or more hand); and from the stratification of elements dating from different epochs on an original 'core', to the artificial 'compaction' of codices or fragments of codices of different origins. Accordingly, this category was (provisionally) excluded from the

25 The following, in chronological order of publication, are the catalogues that were found to be usable: Mercati / Franchi de' Cavalieri 1923 [329 mss]; Franchi de' Cavalieri 1927 [27 mss]; Devreesse 1950 [263 mss]; Giannelli 1950 [199 mss]; Capocci 1958 [163 mss]; Giannelli / Canart 1961 [61 mss]; Canart 1966 [14 mss]; Canart 1970 [218 mss]; Lilla 1985 [93 mss]; Schreiner 1988 [66 mss]; Mogenet / Leroy / Canart 1989 [118 mss].

26 Clearly, the 'five leaves' represent an approximation, since, given the variations in format and page utilisation, they can potentially bear a highly variable amount of text. In any event, one is dealing with texts that can safely be defined as 'brief'. 
study, thus limiting it-for now-to volumes characterised in catalogues as mono-block. ${ }^{27}$

As has already been stressed, the 'non-unitary' manuscript is clearly a complex product in which needs and motivations of an intellectual nature have inevitably to be reconciled with the characteristics and structural limitations of the codex form. Prior to carrying out an examination of content, which is to say an examination of the aggregations of texts represented in codices, and of their reciprocal relationships and evolution over time, it seems appropriate to start with an evaluation of the 'non-unitary' codex from the purely material standpoint, that is to say as a parallelepiped whose visual impact and functionality are determined by the combination of its three dimensions ${ }^{28}$. While the first two dimensions (height and width) are normally noted in catalogues, the third dimension-i.e. the thickness of the quire block-can be indirectly and roughly estimated by means of the 'number of leaves' (overall thickness) parameter, which very likely served as a rough and ready indicator of the thickness of the book block for medieval artisans too. ${ }^{29}$

A first point to underscore is that during the planning phase of a Byzantine manuscript, whether it be 'unitary' or 'non-unitary', the thickness of the quire block was not a parameter left purely to chance ${ }^{30}$ : this can be clearly demonstrated by the fact that in the highly disparate collection of 1,435 (both 'unitary' and 'non-unitary') manuscripts taken into consideration (distributed over a timeline traversing some eight centuries), the most representative ${ }^{31}$ overall thickness value, which is quite pronounced, registers at 200 leaves (Chart 1), whilst only $3 \%$ of the codices surveyed were found to be composed of fewer than 40 leaves. ${ }^{32}$

27 This limitation, albeit an inevitable one, proved particularly disappointing, given that the presence or absence of an underlying plan and, in the affirmative case, degrees to which and ways in which such a plan manifests itself, are indispensable elements for understanding (partially, at least) the relationship that the medieval user had with the miscellaneous book, which otherwise remains incomprehensible to the modern scholar.

28 Concerning this approach to the problem, Muzerelle / Ornato 2004, to which one can usefully refer for more detailed information on its theoretical implications.

29 It is obvious that the two parameters-thickness of the quire block and overall thickness-do not fully coincide, owing to the wide variation in thickness of the paper or parchment sheets from which they were formed.

30 The same affirmation is also valid for the Latin codex: see Muzerelle / Ornato 2004, $56 \mathrm{ff}$ [in this volume, 377-412].

31 Or alternatively, in statistical terminology, the distribution's mode.

32 In roll production, the limitations imposed by the material's structural characteristics (normally resulting in a total length not exceeding 5 metres) in all likelihood exerted some degree of 


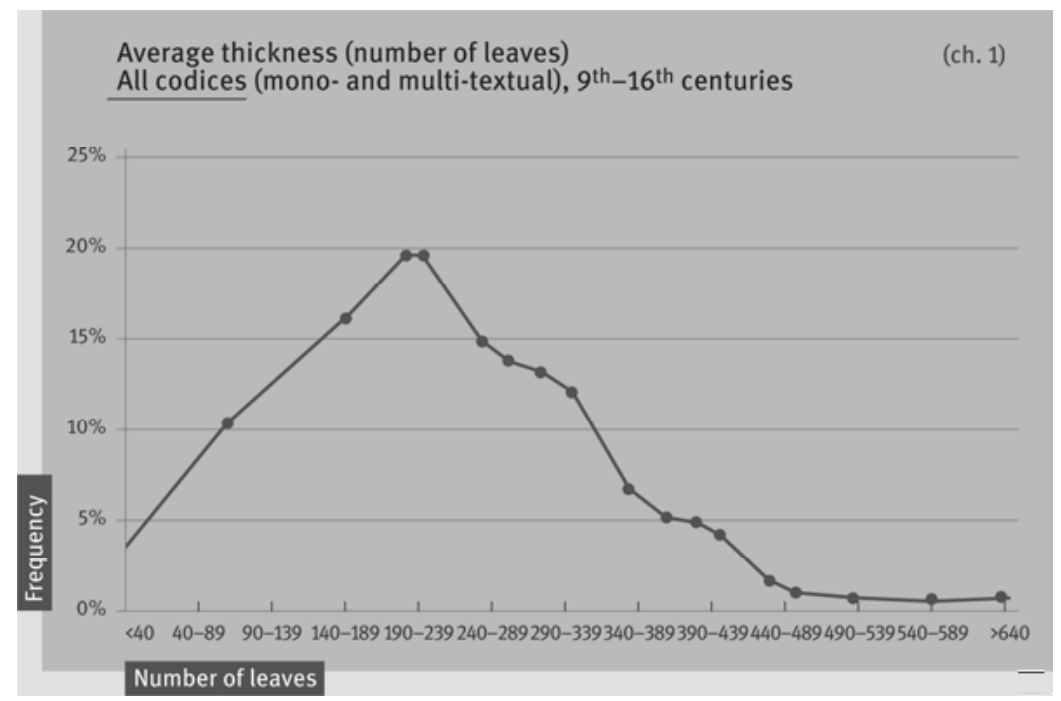

Chart 1: Average thickness (number of leaves). All codices (mono- and multi-textual), $9^{\text {th }}-16^{\text {th }}$ centuries

Needless to say, the thickness parameter has to be assessed not only in absolute terms but also in relation to a volume's other two dimensions, which can be expressed in condensed form through their sum (semi-perimeter, or size). ${ }^{33}$ The relationship between thickness and size shows that thickness is always greater in larger codices. The variation in the number of leaves in relation to volume size does not, however, follow a linear trend: in fact, thickness proves to be relatively

influence on authors as regards the length and internal structuring of texts-judging, that is, from the correspondence between individual rolls and composite units (e.g. the books of Homer, orations/sermons, history tomes, etc.). The progressive positive reception of the codex opened the way to new possibilities for the aggregation of multiple texts in the form of sylloges or corpora, whilst at the same time apparently resulting in a progressive, although not total, disappearance of codices 'bearing a single text or corpuscula-codices'. For a thorough and well-documented examination of this process, albeit limited to Greek manuscripts, see Cavallo 1986, 83-172 and 246-271, text quoted from 162 (also in Cavallo 2002, 49-175).

33 It has been noted that size is not the only possible compact indicator which serves to represent the dimensions of a codex (for a list of possible alternatives, see Gumbert 2001). Though not without limitations, the use of this parameter is in any event encouraged on account of the ease with which it can be calculated, in addition to its wide diffusion in bibliographies concerning the mise en page (see also Maniaci 2002, 72-73). 
lower in the largest volumes and relatively higher in the smallest ones. ${ }^{34}$ The explanation for this phenomenon probably lies in the fact that below a given page size threshold the length of the text to be transcribed (text mass) inevitably has an effect on the number of leaves required to contain it, which as a result is greater (Chart 2).

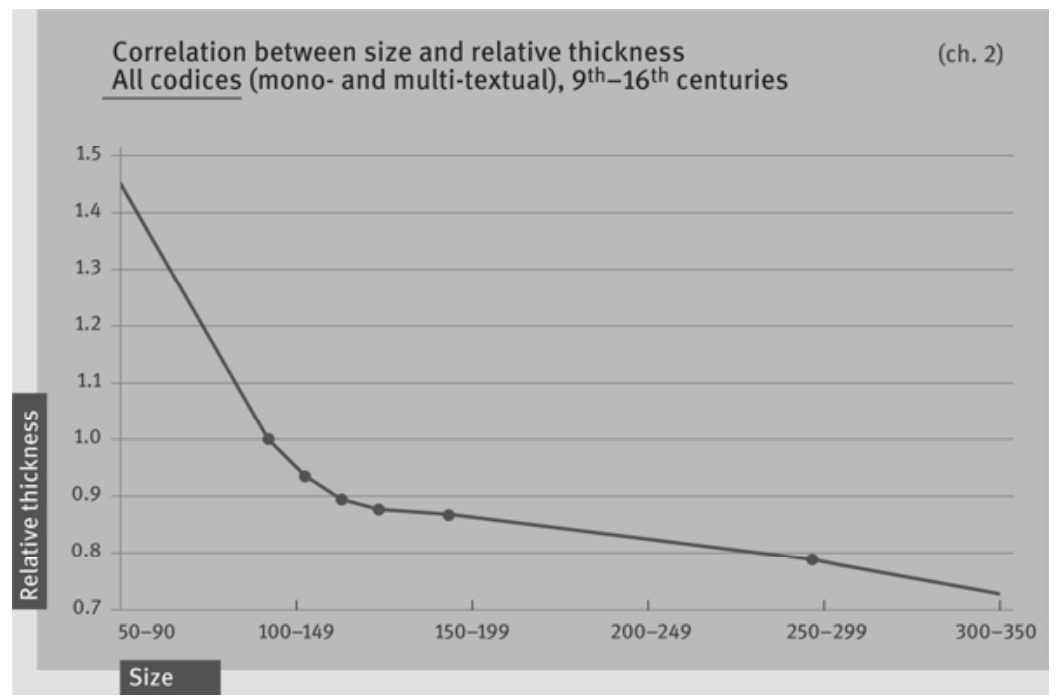

Chart 2: Correlation between size and relative thickness. All codices (mono- and multi-textual), $9^{\text {th }}-16^{\text {th }}$ centuries

The analysis of the thickness of Byzantine manuscripts-both 'unitary' and 'non-unitary'-also uncovers a significant diachronic evolution over time. Unfortunately, the only approximate dates provided in catalogues compel one to adopt a rough timeline divided into centuries that fails to convey the 'epochal' shifts which occurred during the course of Byzantine history, especially with respect to the halt in output (in the middle of the $15^{\text {th }}$ century) caused by the fall of Constantinople, which resulted in the migration of Greek manuscript production centres towards the West. Nevertheless, even a cursory scanning of the rather rudimentary timeline allows one to make out some reasonably welldefined basic trends occurring over time.

34 The situation discerned for the Latin codex is comparable; see Muzerelle / Ornato 2004, 58 [in this volume, 377-412]. 
The first of these trends consists in a progressive reduction in the average thickness of codices over time. This phenomenon is already quite evident in the period spanning the $9^{\text {th }}$ to $11^{\text {th }}$ centuries, and becomes distinctly more pronounced in the late- and, above all, post-Byzantine period (Chart 3).

If the appearance of volumes containing fewer than 40 leaves that occurs between the $13^{\text {th }}$ and $14^{\text {th }}$ centuries can be interpreted as the result of an overall reduction in the average size of codices, the reduction in thickness bears all the hallmarks of an independent phenomenon in the post-Byzantine period (i.e. $15^{\text {th }}-16^{\text {th }}$ centuries) (Tab. 1$) .^{35}$

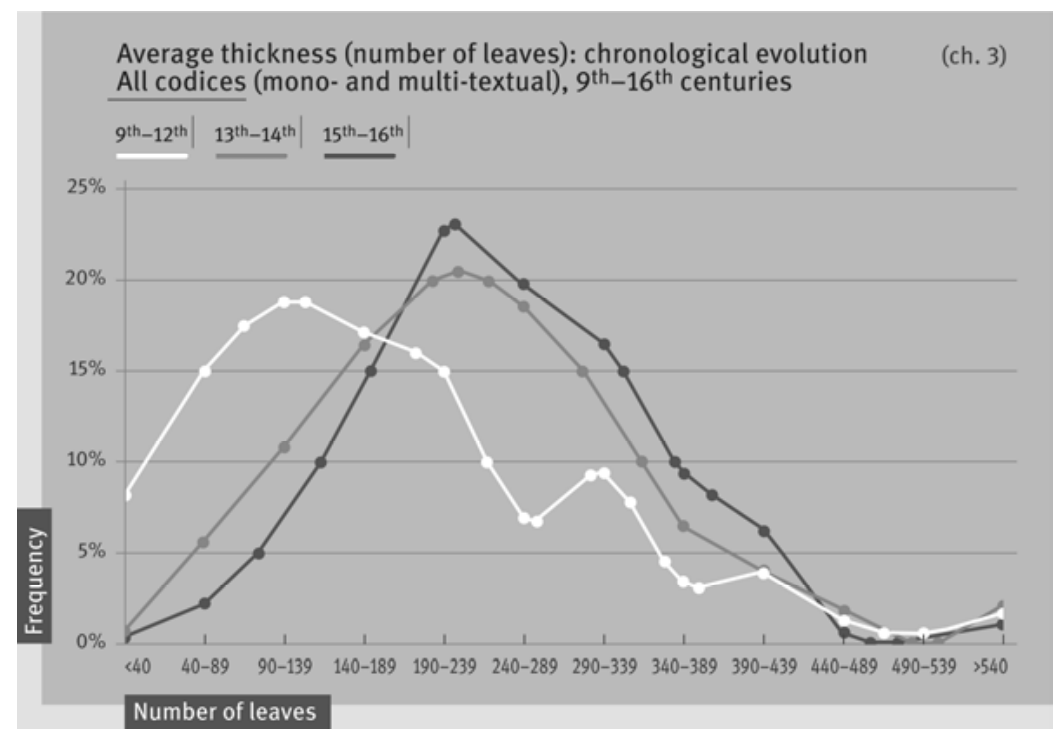

Chart 3: Average thickness (number of leaves): chronological evolution. All codices (mono- and multi-textual), $9^{\text {th }}-16^{\text {th }}$ centuries

35 Given that a significant portion of book production after the middle of the $15^{\text {th }}$ century took place in the West, it would be interesting to evaluate the tendency towards a reduction in size in relation to the working habits adopted in the Latin context (unfortunately, this parameter is not included among those taken into account in the essay by Cartelli / Palma / Ruggiero 2004). 
Average dimensional characteristics of mono- and

(tab. 1) multi-textual codices

\begin{tabular}{|c|c|c|c|c|}
\hline Century & $\begin{array}{l}\text { Overall } \\
\text { thickness }\end{array}$ & Size & $\begin{array}{l}\text { Height / } \\
\text { number of lines }\end{array}$ & $\begin{array}{l}\text { Thickness of } \\
\text { longest text }\end{array}$ \\
\hline $1^{9^{\text {th }}-12^{\text {th }}}$ & |253.69 & $\left.\right|^{514}$ & |10.36 & |174.42 \\
\hline $13^{\text {th }}-14^{\text {th }}$ & |238.11 & 1434 & |9.77 & 163.61 \\
\hline $15^{\text {th }}-16^{\text {th }}$ & |188.65 & $1^{433}$ & |10.61 & |119.05 \\
\hline | Totality & |223.10 & |457 & 10.29 & 148.53 \\
\hline
\end{tabular}

Tab. 1: Average dimensional characteristics of mono- and multi-textual codices

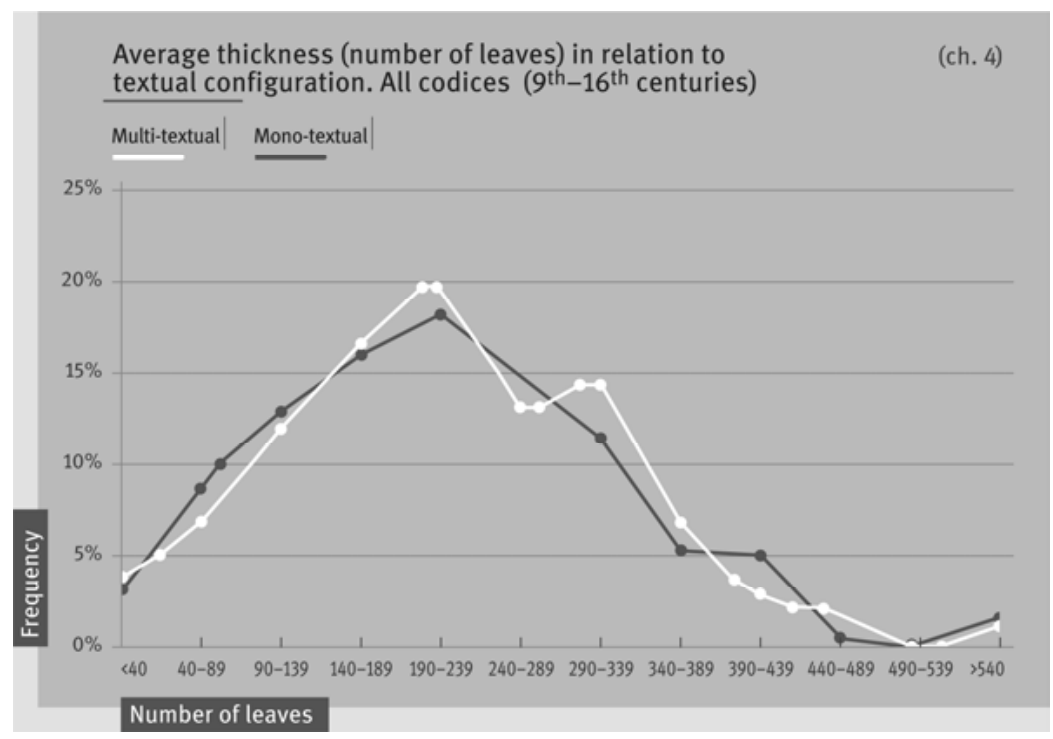

Chart 4: Average thickness (number of leaves) in relation to textual configuration. All codices $\left(9^{\text {th }}-16^{\text {th }}\right.$ centuries)

How, then, from the standpoint of thickness, can the difference between codices containing a single text and those consisting of a juxtaposition of multiple texts be expressed? At an overall level, whether they be mono-textual or multi-textual codices does not seem to exert a significant influence on their average thickness, apart from those which exceed the threshold of 10 texts-an infrequent 
occurrence-which, not surprisingly, is accompanied by an increase in the thickness of the quire block (Chart 4).

However, one can observe that at lower degrees of thickness, the multitextual volumes tend to contain a greater number of leaves in comparison to mono-textual ones: clearly in the Byzantine context the aggregation of multiple texts offered the possibility of regulating the number of leaves so as to reach the minimum number considered ideal for the thickness of the quire block, whilst on the other hand the desire to produce 'unitary' codices made it acceptable to craft slimmer volumes. The earliest periods (from the $9^{\text {th }}$ to $12^{\text {th }}$ centuries), in which multi-textual volumes of greater thickness are proportionately higher in number, represent an exception: in a context where the production of monotextual volumes tended to be the rule, codices composed of multiple texts appear (in contrast with those produced in successive centuries) as associations between lengthy 'core' texts and a group of shorter textual elements 'orbiting' around them (Charts 5, 6, 7). ${ }^{36}$

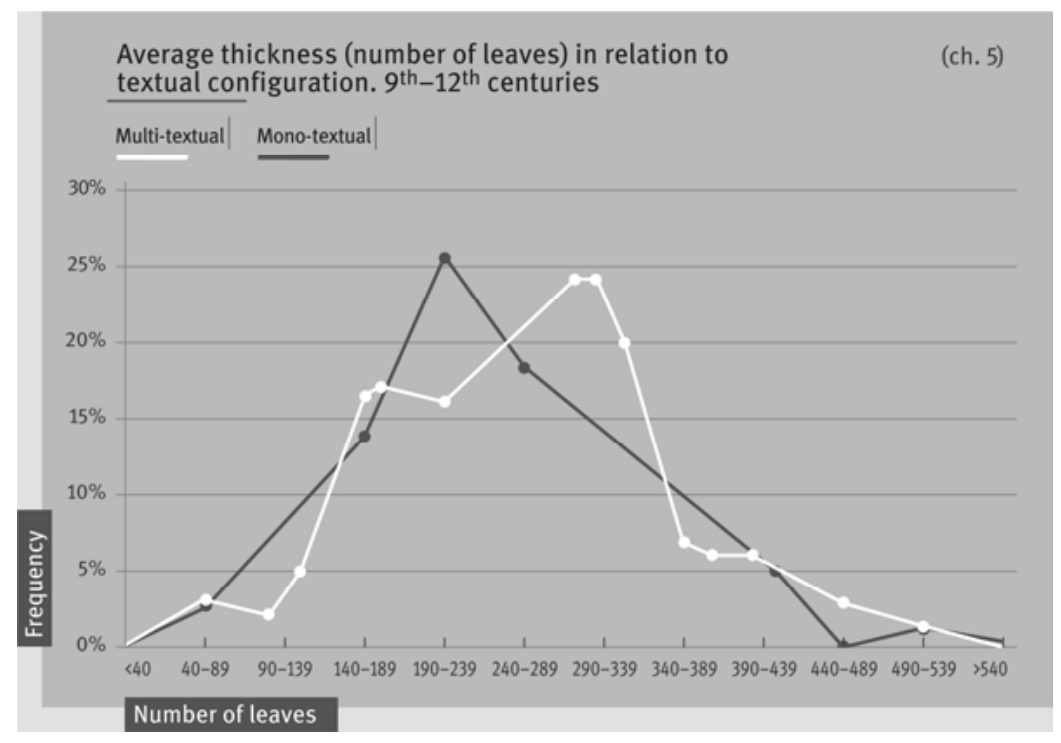

Chart 5: Average thickness (number of leaves) in relation to textual configuration. $9^{\text {th }}-12^{\text {th }}$ centuries

36 In $75 \%$ of the multi-textual codices datable to the $9^{\text {th }}-12^{\text {th }}$ centuries, the longest text consumes more than $50 \%$ of the volume's overall thickness. In $51.3 \%$ of cases the figure exceeds $75 \%$. 


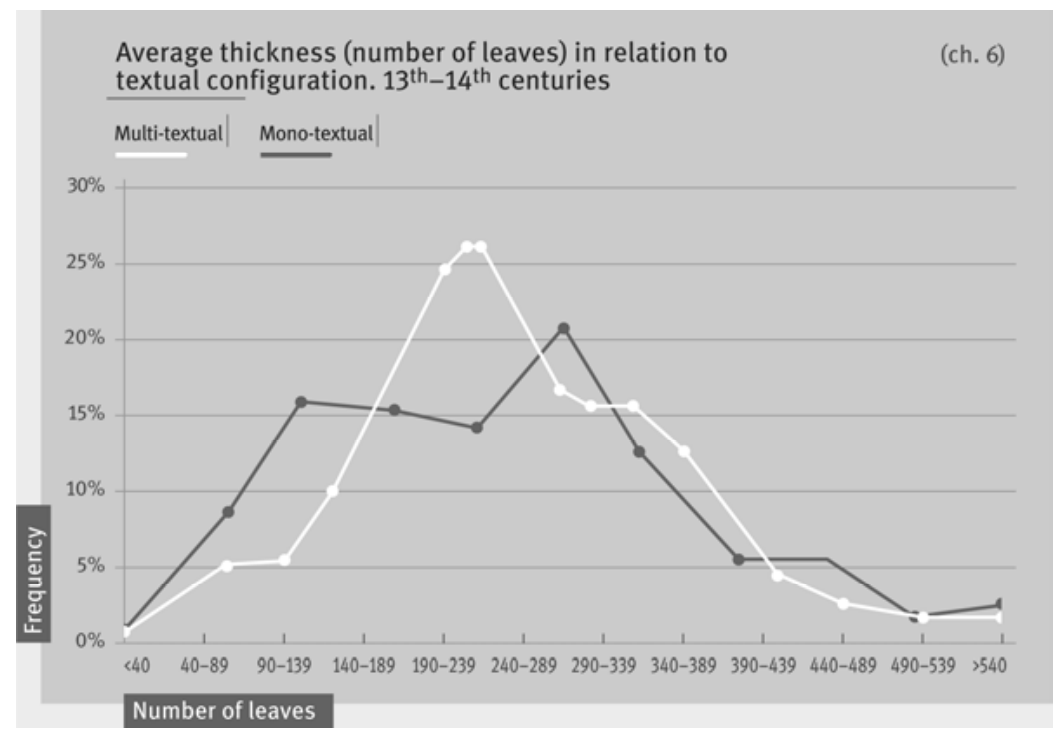

Chart 6: Average thickness (number of leaves) in relation to textual configuration. $13^{\text {th }}-14^{\text {th }}$ centuries

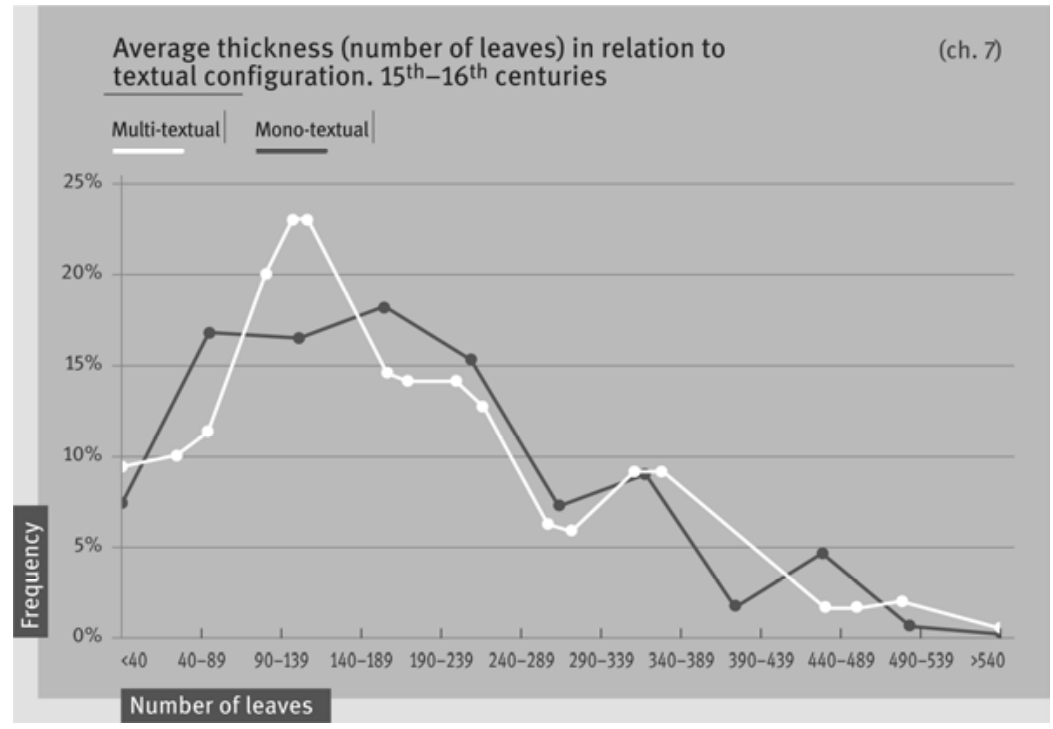

Chart 7: Average thickness (number of leaves) in relation to textual configuration. $15^{\text {th }}-16^{\text {th }}$ centuries 
At a statistical level, the simultaneous presence of more than one text is accompanied by a greater density of writing; indeed, in all the centuries examined, the inter-line space is smaller in the volumes with a higher index of multi-textuality (Chart 8). ${ }^{37}$

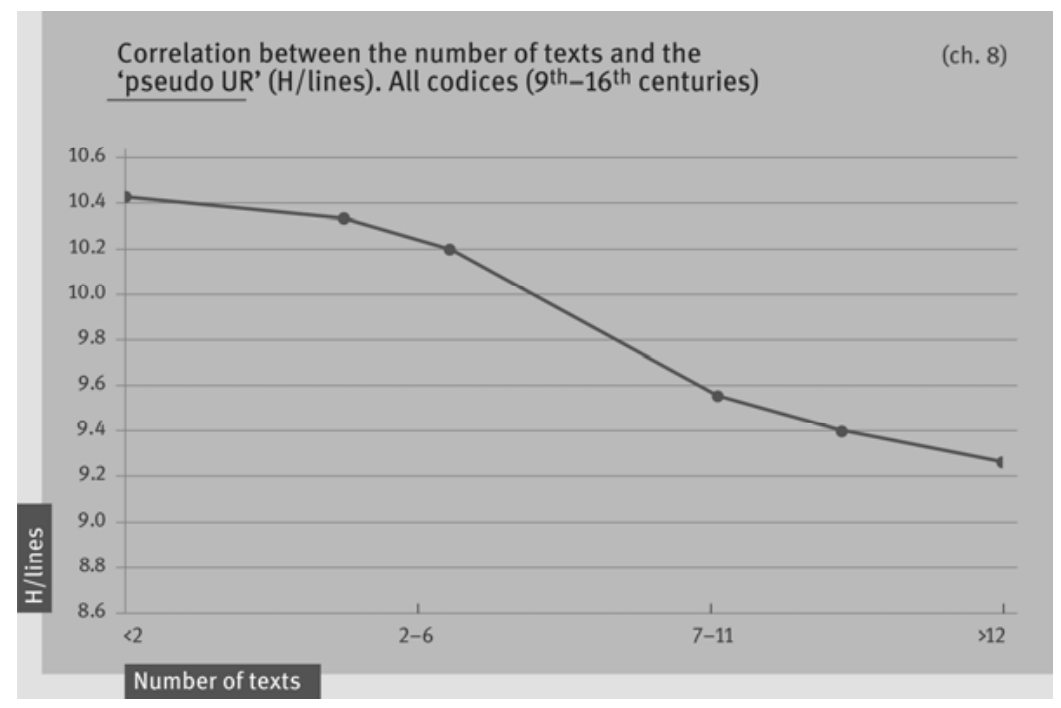

Chart 8: Correlation between the number of texts and the 'pseudo UR' (H/lines). All codices $\left(9^{\text {th }}-16^{\text {th }}\right.$ centuries)

Conversely, the data analysis does not reveal any clear link between the multitextual nature of a volume and its page size, nor between the former characteristic and the arrangement of texts, in the sense that the number of texts accommodated

37 It should, however, be made clear that the number of multi-textual codices dating from the $9^{\text {th }}$ to $10^{\text {th }}$ centuries is too low for the result to be of statistical significance. In reality, the value shown on the chart does not represent an inter-linear measurement, nor that of a unit of ruling ( $\mathrm{UR}=$ unité de réglure, as it is currently defined), which corresponds to the relationship between the height of the writing area and the number of horizontal spaces it is divided into), but instead-in the absence of details on the written area's height, which is not always provided in catalogues-to a 'pseudo-UR', obtained by calculating the relationship between the height of a page and the number of writing lines ruled on it. Even if the correspondence between the two parameters is not perfect (given the considerable variability seen in the sizes of upper and lower margins), they still tally very well at a statistical level. 
by a volume does not appear to be correlated in a clear and linear way to the size of a codex, nor to its layout.

Having determined that thickness, and therefore the height of the page block, is in all respects one of the material constraints imposed on a codex's design, it can be deduced that the odds of a single text entirely monopolising a given codex (of set size) are strictly correlated to its length, measured by the number of leaves it contains: in other words, its specific unitary thickness.

In the case of the Greek codex, the thresholds for unitary thickness that determine the choices made with respect to the merging of texts can vary quite significantly, depending on the historical period they date from. In all cases, the incidence of mono-textual codices in relation to the total grows at the same rate as the increase in the number of leaves required for the transcription of a single text (Tab. 2). For multi-textual codices this finding remains the same, whether one considers the length of the first text (as in the table), or the longest documented text, given that the two-as will become clear later on-are essentially equivalent.

\begin{tabular}{|c|c|c|c|}
\hline \multirow[b]{2}{*}{ Number of leaves of the first text } & dices in re & \multirow[b]{2}{*}{$13^{\text {th }}-14^{\text {th }}$} & \multirow[b]{2}{*}{$15^{\text {th }}-16^{\text {th }}$} \\
\hline & $9^{\text {th }-12^{\text {th }}}$ & & \\
\hline > 40 & $4.35 \%$ & $1.18 \%$ & $22.35 \%$ \\
\hline $40-70$ & $28.57 \%$ & $18.52 \%$ & $51.11 \%$ \\
\hline 70-100 & $60.0 \%$ & $45.83 \%$ & $60.47 \%$ \\
\hline |100-130 & $69.23 \%$ & $60.61 \%$ & $67.50 \%$ \\
\hline $130-160$ & $76.19 \%$ & $50.0 \%$ & |77.14\% \\
\hline $160-190$ & $74.19 \%$ & $58.06 \%$ & |92.11\% \\
\hline 190-220 & |90.70\% & $55.56 \%$ & $88.0 \%$ \\
\hline $220-250$ & $92.11 \%$ & $81.48 \%$ & $83.33 \%$ \\
\hline |>250 & |91.20\% & | $76.0 \%$ & $85.33 \%$ \\
\hline Totality & |78.48\% & $47.64 \%$ & |64.51\% \\
\hline
\end{tabular}

Tab. 2: Frequency of mono-textual codices in relation to the length of the first text

In any event, with respect to the overall trend, the output of the $13^{\text {th }}$ to $14^{\text {th }}$ centuries stands out because the phenomenon is less pronounced and, as it were, 'delayed'-in fact, in the periods spanning the $9^{\text {th }}$ to $12^{\text {th }}$ and $15^{\text {th }}$ to $16^{\text {th }}$ centu- 
ries, the percentage of mono-textual codices rapidly increases and reaches its maximum level for texts of lengths ranging from 190 to 220 leaves. Conversely, during the $13^{\text {th }}$ to $14^{\text {th }}$ centuries, mono-textual codices represent the clear majority only in volumes containing more than 220 leaves.

Above all, it should be noted that in the same period the relative percentage incidence of mono-textual volumes is still lower than in previous and successive centuries, irrespective of the overall thickness of individual volumes (Tab. 3).

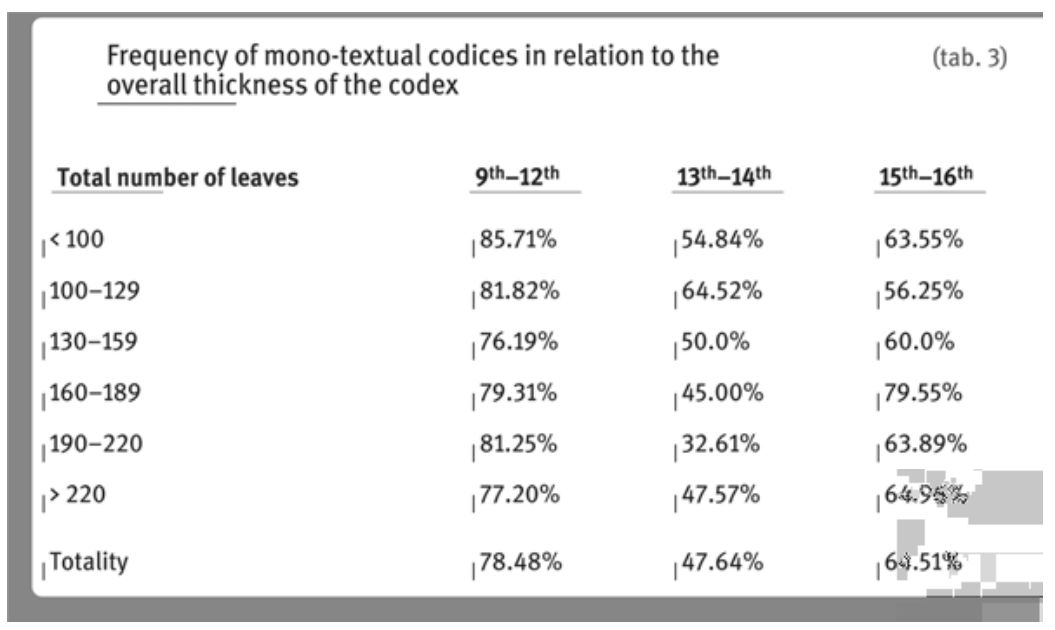

Tab. 3: Frequency of mono-textual codices in relation to the overall thickness of the codex

One can readily deduce that in the earliest phase (i.e. the $9^{\text {th }}$ to $12^{\text {th }}$ centuries), and subsequently in the post-Byzantine phase, the manufacture of bulkier volumes was not, as a rule, the result of multiple texts being merged, but instead served to accommodate the ampleness of a single, particularly long text. In other words, a propensity towards the production of mono-textual codices prevails, whereas the merging of multiple texts was seen as a secondary option, which from time to time was necessary to resort to in order to transmit texts of shorter length, rather than as a result of a deliberate plan based on specific intellectual demands.

It is not by mere chance, then, that the output of the $13^{\text {th }}$ to $14^{\text {th }}$ centuries is characterised, overall, by a significantly greater percentage of multi-textual codices, amounting to some $52 \%$, as opposed to $21 \%$ in the $9^{\text {th }}$ to $12^{\text {th }}$ centuries, and $35 \%$ in the $15^{\text {th }}$ to $16^{\text {th }}$ centuries. Therefore, one can deduce that there was effectively a change in habits, which consisted in abandoning the clear predilection for 
mono-textual codices that prevailed in the previous centuries, and which subsequently reappeared, albeit to a much lesser degree, at the end of the Middle Ages.

Regardless of such a well-delineated chronological evolution, multitextualism in Byzantine book production is a phenomenon whose overall occurrence should not be overstated. Above all, it is worth noting that most multitextual volumes-roughly half-in all periods take the form of juxtapositions of only two or three texts, whereas the percentage of codices containing more than five texts is rather limited, apart from in the period stretching from the $13^{\text {th }}$ to $14^{\text {th }}$ centuries, a peculiar situation which, once again, is plain to see (Tab. 4).

\begin{tabular}{|c|c|c|c|}
\hline \multicolumn{3}{|c|}{$\begin{array}{l}\text { Frequency of textual aggregations (from } 1 \text { to more } \\
\text { than } 5 \text { texts) according to centuries }\end{array}$} & \multirow[t]{2}{*}{ (tab. 4} \\
\hline Number of texts & $9^{\text {th }}-12^{\text {th }}$ & $13^{\text {th }}-14^{\text {th }}$ & \\
\hline Mono-textual & |78.57\% & | $48.39 \%$ & $64.93 \%$ \\
\hline $2-5$ texts & $17.21 \%$ & $30.79 \%$ & $27.25 \%$ \\
\hline More than 5 texts & | $4.22 \%$ & |20.82\% & | $7.82 \%$ \\
\hline |Totality & $100 \%$ & $100 \%$ & |100\% \\
\hline
\end{tabular}

Tab. 4: Frequency of textual aggregations (from 1 to more than 5 texts) according to centuries

On the other hand, one should be aware that the number of texts gathered in a single codex is not, in and of itself, a sufficient basis to define it as being multi-textual, but instead has to be associated with a close examination of the length of each component text. Here, the chief point to note is that the longest text (or principal text) on average occupies, up until the $14^{\text {th }}$ century, a significant portion of the entire codex-equivalent, in fact, to a little over $60 \%$ of the total space.

If, from this standpoint, there is no great difference between the middle-, late- and post-Byzantine periods, there is, on the other hand, a rather marked disparity in relation to the number of 'mini-texts' (i.e. texts with a unitary thickness of fewer than five leaves), which is distinctly higher in the $13^{\text {th }}$ and $14^{\text {th }}$ centuries.

In this period, then, the increase of multi-textual volumes manifests itself as a very hierarchical phenomenon, characterised by the positioning of one or more smaller units around a dominant 'core' text. Only at the end of the Mid- 
dle Ages does the aggregation of multiple texts appear to take a more 'equal' footing, in the sense that the percentage of space occupied by the dominant text descends from $61 \%$ to $49 \%$ (Tab. 5).

\begin{tabular}{|c|c|c|c|}
\hline \multicolumn{3}{|c|}{$\begin{array}{l}\text { Typology of multi-textual codices on the basis of the } \\
\text { number and length of the texts they contain }\end{array}$} & \multirow[b]{2}{*}{$\begin{array}{l}\% \text { of texts of } \\
\text { fewer than } 5 \text { leaves }\end{array}$} \\
\hline Century & $\begin{array}{l}\text { Average number } \\
\text { of texts }\end{array}$ & $\begin{array}{l}\% \text { of space occupied } \\
\text { by the main text }\end{array}$ & \\
\hline $9^{9^{\text {th }}-12^{\text {th }}}$ & |4.83 & $62.12 \%$ & $1.93 \%$ \\
\hline $1^{13^{\text {th }}-14^{\text {th }}}$ & |6.81 & $61.36 \%$ & $6.22 \%$ \\
\hline $1^{15^{\text {th }}-16^{\text {th }}}$ & |4.86 & | $49.32 \%$ & |2.80\% \\
\hline |Totality & 5.73 & $56.92 \%$ & $4.19 \%$ \\
\hline
\end{tabular}

Tab. 5: Typology of multi-textual codices on the basis of the number and length of the texts they contain

If one examines only multi-textual codices in which a single text (out of a minimum total of three) occupies at least $60 \%$ of the available space, it also appears that the principal text, in all periods, was placed in first position (i.e. represents the opening text). This preference becomes all the more clear in the $9^{\text {th }}$ to $12^{\text {th }}$ centuries, but is also maintained in the successive centuries, whilst middle position incidence remains more or less consistent. On the other hand, an increased incidence of the principal text in the last position can be affirmed, perhaps due to the tendency to equip the dominant text with one or more introductory 'mini-texts' (Tab. 6). 
Position of the longest text

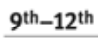

$13^{\text {th }}-14^{\text {th }}$

$15^{\text {th }}-16^{\text {th }}$

Opening section

| $77.78 \%$

$59.18 \%$

$57.14 \%$

Central section

$11.11 \%$

$14.29 \%$

$14.29 \%$

Final section

$11.11 \%$

$26.53 \%$

$28.57 \%$

Totality

$100 \%$

$100 \%$

$100 \%$

Tab. 6: Position of the longest text (principal text)

Finally, a fundamental aspect of the 'physiognomy' of the multi-textual codex remains to be examined, namely the way in which texts were juxtaposed based on a volume's content.

The following observations are intended to provide some hints that would be worthwhile to further develop as part of a more in-depth evaluation of a phenomenon which is difficult to tackle solely on the basis of descriptions of content provided in catalogues.

An initial subdivision of the corpus based on a dichotomy set up between the 'sacred/secular' typologies confirms the impression that the multi-textual codex, even if it was widely adopted, represents a phenomenon which is more specific to the secular realm. 
In all the chronological groups investigated, the percentage of volumes containing sacred texts (i.e. Bibles, commentaries on the Bible, liturgical works, theological works, hagiographies and homilaries, etc.), is indeed greater among 'unitary' volumes than in those which contain associations of multiple texts. Between the mid- and late-Byzantine eras the phenomenon is accentuated by a generalised increase in the output of books of a secular nature (i.e. philology and rhetorics, poetry, historiography, science, philosophy, law etc.), exemplified, in multi-textual volumes, by a clear reduction in the number of sacred texts among the first five texts surveyed in each individual codex (Tab. 7).

\begin{tabular}{|c|c|c|c|}
\hline \multirow[b]{2}{*}{ Codices } & \multirow{3}{*}{$\begin{array}{l}9^{\text {th }}-12^{\text {th }} \\
77.07 \%\end{array}$} & \multirow{3}{*}{$\begin{array}{l}13^{\text {th }}-14^{\text {th }} \\
35.30 \%\end{array}$} & \multirow{3}{*}{$\begin{array}{l}\frac{15^{\text {th }}-16^{\text {th }}}{19.58 \%} \\
19 \%\end{array}$} \\
\hline & & & \\
\hline All & & & \\
\hline Mono-textual & $85.08 \%$ & | $48.89 \%$ & $26.49 \%$ \\
\hline Multi-textual & $67.62 \%$ & $31.89 \%$ & $15.44 \%$ \\
\hline
\end{tabular}

Tab. 7: Frequency of textual aggregations (from 1 to more than 5 texts) according to the centuries

In addition, starting from the $13^{\text {th }}$ century, the multi-textual codex of secular content is characterised by a marked propensity to unite a greater number of texts (in the 'five or more texts' category) in comparison to the other content typologies. This tendency can be ascribed at least in part to material factors-on average, the secular texts are shorter and encourage or necessitate unification-and to a certain extent, in all likelihood, to the reading and academic habits of the learned circles within which such codices were produced (Tab. 8). 
Frequency of textual aggregations.

(tab. 8)

Difference between sacred and secular codices

\begin{tabular}{|c|c|c|c|c|c|}
\hline \multirow[t]{2}{*}{ Century } & \multirow[t]{2}{*}{ Number of texts } & \multirow{2}{*}{$\begin{array}{l}\text { Frequency } \\
\text { Secular } \\
\end{array}$} & \multirow[b]{2}{*}{ Sacred } & \multicolumn{2}{|c|}{$\begin{array}{l}\text { Number of leaves in } \\
\text { longest text }\end{array}$} \\
\hline & & & & Secular & Sacred \\
\hline \multirow{4}{*}{$1^{9^{\text {th }}-12^{\text {th }}}$} & |Mono-textual & $14.92 \%$ & $85.08 \%$ & $\left.\right|^{215.08}$ & 256.82 \\
\hline & $1^{2-4}$ texts & $30.23 \%$ & $69.77 \%$ & |53.69 & 175,22 \\
\hline & $1^{5}$ and more & |26.09\% & |73.91\% & | 33.50 & 149.62 \\
\hline & | Totality & $17.83 \%$ & $83.17 \%$ & |158.16 & |240.26 \\
\hline \multirow[t]{4}{*}{$13^{\text {th }}-14^{\text {th }}$} & |Mono-textual & |51.11\% & $48.89 \%$ & $\left.\right|^{210.33}$ & | 259.70 \\
\hline & $1^{2-4}$ texts & |59.21\% & | $40.79 \%$ & | 106.78 & 187.32 \\
\hline & $1^{5}$ and more & | $71.30 \%$ & $28.70 \%$ & | 69.54 & |111.32 \\
\hline & | Totality & $59.03 \%$ & | $40.97 \%$ & 136.33 & |212.73 \\
\hline \multirow[t]{4}{*}{$15^{\text {th }}-16^{\text {th }}$} & |Mono-textual & $73.51 \%$ & $26.49 \%$ & |182.13 & 216.08 \\
\hline & 2-4 texts & | $72.62 \%$ & $27.38 \%$ & | 101.81 & 123.76 \\
\hline & $1^{5}$ and more & | $87.93 \%$ & | $12.07 \%$ & |54.91 & 152.93 \\
\hline & | Totality & $75.37 \%$ & $24.63 \%$ & 145.28 & 183.75 \\
\hline
\end{tabular}

Tab. 8: Frequency of textual aggregations. Difference between sacred and secular codices

Concerning the simultaneous presence of sacred and secular texts within a single codex, full homogeneity (i.e. either exclusively secular or exclusively sacred texts) represents the norm in all periods, whereas the mixing of texts-as in unorganised multi-textual codices-should be considered an exception (Tab. 9). 
Homogeneity / heterogeneity of textual associations

(tab. 9) (sacred and secular content)

$\begin{array}{lll}\text { Century } & \text { Homogeneity } & \text { Mixed } \\ { }-12^{\text {th }} } } & \mid 86.36 \% & \mid 13.64 \% \\ \left.\right|^{13^{\text {th }}-14^{\text {th }}} & \left.\right|^{76.44 \%} & \mid 23.56 \% \\ \left.\right|^{15^{\text {th }}-16^{\text {th }}} & \mid 85.92 \% & \mid 14.08 \% \\ \left.\right|^{\text {Totality }} & \mid 81.45 \% & \mid 18.55 \%\end{array}$

Tab. 9: Homogeneity / heterogeneity of textual associations (sacred and secular content)

Characteristics of multi-textual codices in relation to the prevailing textual typology

(tab. 10)

\begin{tabular}{|c|c|c|c|c|}
\hline Typology of the longest text & $13^{\text {th }}-14^{\text {th }}$ & & $15^{\text {th }}-16^{\text {th }}$ & \\
\hline & $\%$ multi-textual & $\%$ mini-texts & $\%$ multi-textual & $\%$ mini-texts \\
\hline Bible & |7.14\% & |1.16\% & |16.67\% & $10 \%$ \\
\hline Hagiography & |20.0\% & |1.93\% & $25.0 \%$ & $1^{4.50 \%}$ \\
\hline Historiography & |26.32\% & $2.86 \%$ & |13.64\% & |0.31\% \\
\hline Bible commentaries & |29.17\% & $2.29 \%$ & |11.11\% & | $0 \%$ \\
\hline Philosophy & | $40.54 \%$ & $1.38 \%$ & |22.22\% & |0.35\% \\
\hline Theology & | $44.44 \%$ & | $0.20 \%$ & 140.0\% & । $0,17 \%$ \\
\hline Liturgy & | $45.45 \%$ & $2.71 \%$ & 140.0\% & $10 \%$ \\
\hline Homiletics & | 48.15\% & । $0.30 \%$ & |22.22\% & $10 \%$ \\
\hline Literature & |58.82\% & । $4.16 \%$ & । $40.30 \%$ & | $0.89 \%$ \\
\hline Science & | $64.52 \%$ & |11.20\% & $52.08 \%$ & 1.94\% \\
\hline Philosophy ad rhetorics & । 70.59\% & | $10.28 \%$ & $37.84 \%$ & । $4.15 \%$ \\
\hline Totality & $51.48 \%$ & $5.46 \%$ & $34.63 \%$ & $2.84 \%$ \\
\hline
\end{tabular}

Tab. 10: Characteristics of multi-textual codices in relation to the prevailing textual typology 
That being said, the tendency towards 'non-unitary' content is not the same in all text typologies (Tab. 10)..$^{38}$

Up until the $12^{\text {th }}$ century, the minority representation of multi-textual codices makes it impossible to carry out a sufficiently detailed analysis; one must therefore limit oneself to observing that the number of such texts exceeds $10 \%$ of the total only in the cases of theological and homiletic writings.

In the succeeding $13^{\text {th }}$ and $14^{\text {th }}$ centuries, if we use the longest type of text as a benchmark, it becomes clear that the widespread increase in multi-textual codices encompasses, albeit in a non-uniform way, all text categories. However, the increase is seen at its maximum in volumes of literary and scientific content and is clearly related to the proliferation of the aforementioned 'mini-texts', usually arranged around a ‘core' text.

Conversely, in the post-Byzantine period one observes a fresh reduction in the overall number of multi-textual volumes which affects-albeit to a variable extent-the majority of content typologies. This trend can be ascribed, at least in part, to the drastic reduction in 'mini-texts', in addition to, more generally speaking, the already mentioned reduction in the average thickness of the individual transcribed texts.

The observations made up to this point represent a first attempt to apply a codicological approach to the particular set of problems associated with the 'non-unitary' codex. As such, they can be regarded as suggestions for further research, and therefore represent issues that require greater clarification, indepth study and verification. What, then, are the overall conclusions that we can draw at this stage, albeit only tentatively?

Even if the production of multi-textual codices has to be assessed in the light of the particular circumstances and historico-cultural contexts that it was an expression of, it also necessarily has to be examined within the material setting that governed the length of texts (measured by the number of leaves in a volume) and the inescapable functional and aesthetic influences that the book in the form of a codex was subject to. If a text was too short, it would not have been able to 'monopolise' an entire codex; if, on the other hand, it was very long, the addition of further texts had to be curbed so as to avoid the risk of spoiling the aesthetic appeal and handling characteristics of the volume.

38 The textual typologies that appear in the table are similar to those employed by Maniaci 2002, which in turn (after a certain amount of simplification) were drawn from those adopted by Sautel 1995. For the present investigation, it was decided to augment the level of detail for the classification of secular texts. 
In the $9^{\text {th }}$ to $12^{\text {th }}$ centuries, when, taken as a whole, the creation of volumes of a sacred nature prevailed, multi-textuality should be seen as a marginal phenomenon-albeit significant in individual cases-within the overall panorama of manuscript production in the Greek language. The ideal aimed at certainly seems to have been the mono-textual codex-an ideal whose fulfilment was made easier by the fact that the percentage of codices of limited overall thickness, which is to say containing fewer than 150 leaves, totals only $11 \%$ (in comparison to $20 \%$ in the $13^{\text {th }}$ to $14^{\text {th }}$ centuries, and $35 \%$ in the $15^{\text {th }}$ to $16^{\text {th }}$ centuries).

The $13^{\text {th }}$ and $14^{\text {th }}$ centuries can be clearly distinguished by a considerable increase of the number of multi-textual codices produced. Without doubt, this was the consequence of profound changes of an intellectual nature that translated, in turn, into changes in book production, given that the increased presence of volumes containing multiple texts is relatively independent from their overall thickness and affects almost all content typologies, albeit in a rather heterogeneous way and not without exceptions (for example, the number of multitextual codices is lower among those containing solely or predominantly biblical, hagiographical or homiletic material).

The phenomenon is, however, magnified by various factors that produce convergent effects. Above all, this process manifests itself through a great emphasis among manuscripts containing secular material, the production of which in this period prevails. On average, in this type of codex the length of texts is lower, which favours-when it does not indeed dictates-the production of multi-textual volumes. Furthermore, there is a significant increase in the presence of 'mini-texts' consisting of fewer than 5 leaves.

In the $15^{\text {th }}$ to $16^{\text {th }}$ centuries, a considerable reduction is once again seen in the number of multi-textual codices. This reduction coincides with a drastic diminution in the percentage of 'mini-texts', including in the typologies in which these were previously used in significant numbers. If the contraction in multi-textual codices does not assume vast proportions, this is partly because the average length of texts underwent an obvious reduction, which provided-as has already been pointed out-impetus for their unification. This represents a real phenomenon (independent, that is, from a greater exploitation of the available space on pages) and is made evident the quantitative analysis, although its significance cannot be investigated in greater depth using this tool alone.

In essence, only during the $13^{\text {th }}$ and $14^{\text {th }}$ centuries did the multi-textual form, in Byzantine manuscripts, amount to a fully autonomous phenomenon; that is to say one which enjoyed genuine independence from the material constraints that exerted an influence on the manufacture of codices. From the historicocultural standpoint, Guglielmo Cavallo's studies have richly documented the 
activities of writing circles in the Palaeologan Age, when 'often more than one hand participated in the editorial set-up of texts, ${ }^{39}$ and the reciprocal relationships between reading, study and transcription were very close, particularly-but not solely-in relation to Greek literature of the Classical Age.

Not by chance, it is among volumes dating from the Palaeologan Age that one encounters the highest number of volumes that we have previously defined as organised multi-textual multi-block codices. These include volumes that are the result of the stratification of multiple parts transcribed at different times by one and the same copyist; volumes transcribed by two (or rarely more than two) copyists operating in concert, most likely to divide labour (although probably not exclusively for this reason); and the convergence of multiple booklets that were originally circulated as independent items, including those dating from different historical periods, if such a convergence can be attributed to the editorial work of a learned 'inspirer', or alternatively to the shared academic activities of a particular group of erudite people.

A phenomenon that is quite distinct from the multi-textual book is that of the codex's 'structural modularity', independent of the number of texts (ranging from one to many) that it contains. The view that, in the absence of external constraints, the, as it were, 'spontaneous' choice on the part of the artisan would have been to produce a 'monolithic' volume (i.e. a structurally 'unitary' one) has been too hastily arrived at. If we reject this vision, which is informed by modern expectations that identify the 'unitary' codex with a more finished, stable and, in essence, 'beautiful' product, we could even support the hypothesis that the 'modular' manuscript constituted, in the eyes of the medieval man, a more 'sophisticated' product than today's 'unitary' book, precisely on account of its intrinsic potential to be dismantled, re-aggregated, modified and added to according to the specific tastes and needs of individual users. Various pieces of evidence (e.g. quire signatures or sequences of medieval corrections or comments juxtaposed in different series in one and the same codex, or in a single series, but one which is different from that seen today), suggest that, in contrast to our modern notion of a book as a unitary and indissoluble entity, and hence an inexorably 'fixed' entity (i.e. impossible to dismantle and/or to merge with other books or parts of books), the medieval volume was instead seen as a 'dynamic' object harbouring the potential, from the moment of its creation, to be arranged or rearranged according to particular needs or circumstances-and was indeed often treated in this way.

39 Cavallo 2001, 606. 
However, only by examining different historical eras and text typologies by means of a systematic application of the analytical tools used in codicological research would it be possible to substantiate such a hypothesis.

\section{References}

Bianconi, Daniele (2004), 'Libri e mani. Sulla formazione di alcune miscellanee dell'età dei Paleologi', in Crisci, Edoardo / Pecere, Oronzo (eds) (2004), Il codice miscellaneo. Tipologie e funzione. Atti del convegno internazionale (Cassino, 14-17 maggio 2003), Cassino: Università degli studi di Cassino (= Segno e testo, 2), 311-363.

Bischoff, Frank M. (1994), 'Systematische Lagenbrüche: Kodikologische Untersuchungen zur Herstellung und zum Aufbau mittelalterlicher Evangeliare', in Rück, Peter / Boghardt, Martin (eds), Rationalisierung der Buchherstellung im Mittelalter und in der frühen Neuzeit. Ergebnisse eines buchgeschichtlichen Seminars der Herzog August Bibliothek Wolfenbüttel, $12^{\text {th }}-14^{\text {th }}$ November, 1990, Marburg: Institut für Historische Hilfswissenschaften (Elementa diplomatica, 2), 83-110.

Canart, Paul (1966), Catalogue des manuscrits grecs de l'Archivio di San Pietro, Città del Vaticano: Biblioteca Apostolica Vaticana (Studi e Testi, 246).

Canart, Paul (1970), Bibliothecae Apostolicae Vaticanae codices manu scripti recensiti iussu Pauli VI Pontificis Maximi [...]. Codices Vaticani Graeci. Codices 1745-1962 recensuit Paulus Canart, Tomus I. Codicum enarrationes, in Bibliotheca Vaticana.

Capocci, Valentino (1958), Bibliothecae Apostolicae Vaticanae codices manuscripti recensiti iussu Ioannis XXIII Pontificis maximi [...]. Codices Barberiniani Graeci, Tomus I. Codices 1163 recensuit Valentinus Capocci, in Bibliotheca Vaticana.

Cartelli, Antonio / Palma, Marco / Ruggiero, Silvia (2004), 'I codici miscellanei nel basso medioevo', in Crisci, Edoardo / Pecere, Oronzo (eds), Il codice miscellaneo. Tipologie e funzioni. Atti del convegno internazionale (Cassino, 14-17 maggio 2003), Cassino: Università degli studi di Cassino (= Segno e testo, 2), 245-309.

Cavallo, Guglielmo (1986), 'Conservazione e perdita dei testi greci: fattori materiali, sociali, culturali’, in Giardina, Andrea (ed.), Tradizione dei classici, trasformazioni della cultura, Roma-Bari: Istituto Gramsci (Seminario di antichistica. Società romana e impero tardoantico, 4), 83-172 and 246-271 (also in Cavallo, Guglielmo [2002], Dalla parte del libro. Storie di trasmissione dei classici, Urbino: QuattroVenti, 49-175).

Cavallo, Guglielmo (2001), “Foglie che fremono sui rami”. Bisanzio e i classici’, in Settis, Salvatore (ed.), I Greci. Storia Cultura Arte Società, III. I Greci oltre la Grecia, Torino: Einaudi, 593-628.

Devreesse, Robert (1950), Bibliothecae Apostolicae Vaticanae codices manu scripti recensiti iussu Pii XI Pontifici Maximi [...]. Codices Vaticani Graeci. Tomus III. Codices 330-603 recensuit Robertus Devreesse, in Bibliotheca Vaticana.

Franchi De' Cavalieri, Pio (1927), Bibliothecae Apostolicae Vaticanae codices manuscripti recensiti iussu Pii XI Pontifici Maximi [...]. Codices Graeci Chisiani et Borgiani recensuit Pius Franchi De' Cavalieri, Romae. 
Giannelli, Cyrus (1950), Bibliothecae Apostolicae Vaticanae codices manu scripti recensiti iussu Pii XI Pontifici Maximi [...]. Codices Vaticani Graeci. Codices 1485-1683 recensuit Cyrus Giannelli, in Bibliotheca Vaticana.

Giannelli, Cyrus / Canart, Paul (1961), Bibliothecae Apostolicae Vaticanae codices manu scripti recensiti iussu loannis XXIII Pontificis maximi [...]. CodicesVaticani Graeci. Codices 1684-1744 recensuit Cyrus Giannelli t. Addenda et indices curavit Paulus Canart, in Bibliotheca Vaticana.

Gumbert, Johan Peter (1989), 'L'unité codicologique, ou: à quoi bon les cahiers?', in Gazette du livre médiéval, 14: 4-8.

Gumbert, Johan Peter (1999), 'One Book with Many Texts: The Latin Tradition', in JansenSieben, Ria / van Dijk, Hans (eds), Codices Miscellanearum. Brussels Van Hulthem Colloquium / Bruxelles Colloque Van Hulthem 1999, Bruxelles (Archives et bibliothèques de Belgique. Numéro spécial, 60), 27-36.

Gumbert, Johan Peter (2001), 'Livre grand, livre petit: un problème de taille', in Gazette du livre médiéval, 38: 55-58.

Gumbert, Johan Peter (2004), 'Codicological Units: Towards a Terminology for the Stratigraphy of the Non-Homogeneous Codex', in Crisci, Edoardo / Pecere, Oronzo (eds), Il codice miscellaneo. Tipologie e funzioni. Atti del convegno internazionale (Cassino, 14-17 maggio 2003), Cassino: Università degli studi di Cassino, 2004 (= Segno e testo, 2), 17-42.

Hanna, Ralph (1986), 'Booklets in Medieval Manuscripts: Further Considerations', in Studies in Bibliography, 9: 100-111.

Kienhorst, Hans (1996), 'Middelnederlandse handschriften als codicologisch object', in Sonnemans, Gerard (ed.), Middeleeuwse Verzamelhandschriften uit de Nederlanden, Congres Nijmegen 14 oktober 1994, Hilversum: Uitgeverij Verloren (Middeleeuwse Studies en Bronnen, 51), 39-60.

Kienhorst, Hans (2002) [2003], “'Nach der Lektüre das Buch bitte umgehend zurückbringen”. Über die merkwürdige Entstehungsgeschichte der mittelniederländischen Sammelhandschrift Wiesbaden, Hessisches Hauptstaatsarchiv, Hss.-Abt. 3004 B 10', in Das Mittelalter, Perspektiven mediävisticher Forschung. Zeitschrift des Mediävistenverbandes, 7/2 [repr. in Schubert [ed.] 2003], 48-73.

Kwakkel, Erik (2002), 'Towards a Terminology for the Analysis of Composite Manuscripts', in Gazette du livre médiéval, 41: 12-19.

Lilla, Salvatore (1985), Bibliothecae Apostolicae Vaticanae codices manu scripti recensiti iussu Iohannis Pauli Il Pontificis Maximi [...]. Codices Vaticani Graeci. Codices 2162-2254 (Codices Columnenses) recensuit Salvatore Lilla, in Bibliotheca Vaticana.

Maniaci, Marilena (1996 [1998²]), Terminologia del libro manoscritto, Milano, Roma: Istituto centrale per la patologia del libro.

*Maniaci, Marilena (2000), 'La struttura delle Bibbie atlantiche', in Maniaci, Marilena / Orofino, Giulia (eds), Le Bibbie atlantiche. Il Libro delle Scritture tra monumentalità e rappresentazione. Catalogo della mostra, [Milano]: Centro Tibaldi, 47-60.

Maniaci, Marilena (2002), Costruzione e gestione della pagina nel manoscritto bizantino, Cassino: Università degli studi di Cassino.

Mercati, Giovanni / Franchi de' Cavalieri, Pio (1923), Bibliothecae Apostolicae Vaticanae codices manu scripti recensiti iussu Pii XI Pontifici Maximi [...]. Codices Vaticani Graeci recensuerunt lohannes Mercati et Pius Franchi de' Cavalieri. Tomus I. Codices 1-329, Romae: Typis Polyglottis Vaticanis. 
Mogenet, Joseph / Leroy, Julien / Canart, Paul (1989), Bibliothecae Apostolicae Vaticanae codices manu scripti recensiti iussu loannis Pauli Il Pontificis Maximi [...]. Codices Barberiniani Graeci, Tomus II. Codices 164-281 recensuit losephus Mogenet t, enarrationes complevit Iulianus Leroy t, addenda et indices curavit Paulus Canart, in Bibliotheca Vaticana.

Munk Olsen, Birger (1998), 'L'élément codicologique', in Hoffmann, Philippe (ed.), Recherches de codicologie comparée. La composition du codex au Moyen Âge, en Orient et en Occident, Paris: Presses de l'École Normale Supérieure, 105-129.

Muzerelle, Denis (1985), Vocabulaire codicologique. Répertoire méthodique des termes français relatifs aux manuscrits, Paris: CEMI (Rubricae. Histoire du livre et des textes, 1).

*Muzerelle, Denis / Ornato, Ezio (2004), La terza dimensione del libro. Aspetti codicologici della pluritestualità, in Crisci, Edoardo / Pecere, Oronzo (eds), Il codice miscellaneo. Tipologie e funzioni. Atti del convegno internazionale (Cassino, 14-17 maggio 2003), Cassino: Università degli studi di Cassino, 2004 (= Segno e testo, 2), 43-74.

Nichols, Stephen G. / Wenzel, Siegfried (eds) (1996), The Whole Book. Cultural Perspectives on the Medieval Miscellany, Ann Arbor: University of Michigan Press (Recentiores: Later Latin Texts and Contexts).

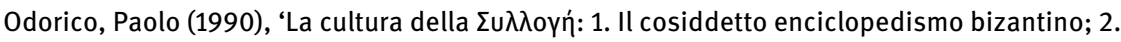
Le tavole del sapere di Giovanni Damasceno', in Byzantinische Zeitschrift, 83: 1-21.

Robinson, Pamela R. (1980), 'The “Booklet”: A Self-Contained Unit in Composite Manuscripts', in Gruys, Albert / Gumbert, Johan Peter (eds), Codicologica, 3. Essais typologiques, Leiden: Brill (Litterae textuales), 46-69.

Sautel, Jacques-Hubert (1995), Répertoire de réglures dans les manuscrits grecs su parchemin. Base de données établie par Jacques-Hubert Sautel à l'aide du fichier Leroy et des catalogues récentes, Turnhout: Brepols (Bibliologia, 13).

Schreiner, Peter (1988), Bibliothecae Apostolicae Vaticanae codices manu scripti recensiti iussu loannis Pauli II Pontificis Maximi [...]. Codices Vaticani Graeci. Codices 867-932 recensuit Petrus Schreiner, in Bibliotheca Vaticana.

Schubert, Martin J. (ed.) (2003), Der Schreiber im Mittelalter, Berlin: Akademie Verlag.

Shailor, Barbara A. (1996), ‘A Cataloger's View', in Nichols, Stephen G. / Wenzel, Siegfried (eds), The Whole Book. Cultural Perspectives on the Medieval Miscellany, Ann Arbor: University of Michigan Press (Recentiores: Later Latin Texts and Contexts), 153-167.

Thorndike, Lynn (1946), 'The Problem of the Composite Manuscript', in Miscellanea G. Mercati, VI, Città del Vaticano: Biblioteca Apostolica Vaticana (Studi e Testi, 126), 93-104. 
